\title{
The Inflammatory Cytokine IL-3 Hampers Cardioprotection Mediated by Endothelial Cell-Derived Extracellular Vesicles Possibly via Their Protein Cargo
}

\author{
Claudia Penna ${ }^{1,+}$, Saveria Femminò ${ }^{2,+}{ }^{+}$Marta Tapparo ${ }^{2}$, Tatiana Lopatina ${ }^{2}$, Kari Espolin Fladmark ${ }^{3}$, \\ Francesco Ravera ${ }^{2}{ }^{(1)}$, Stefano Comità ${ }^{1}$, Giuseppe Alloatti ${ }^{4}$, Ilaria Giusti ${ }^{5}$, Vincenza Dolo ${ }^{5}{ }^{(0)}$, \\ Giovanni Camussi ${ }^{2, * \mathbb{0}}$, Pasquale Pagliaro ${ }^{1, \ddagger \mathbb{1}}$ and Maria Felice Brizzi ${ }^{2, *, \ddagger}$
}

check for updates

Citation: Penna, C.; Femminò, S.; Tapparo, M.; Lopatina, T.; Fladmark, K.E.; Ravera, F.; Comità, S.; Alloatti, G.; Giusti, I.; Dolo, V.; et al. The Inflammatory Cytokine IL-3 Hampers Cardioprotection Mediated by Endothelial Cell-Derived Extracellular Vesicles Possibly via Their Protein Cargo. Cells 2021, 10, 13. https:// dx.doi.org/10.3390 / cells10010013

Received: 23 November 2020 Accepted: 18 December 2020 Published: 23 December 2020

Publisher's Note: MDPI stays neutral with regard to jurisdictional claims in published maps and institutional affiliations.

Copyright: () 2020 by the authors. Licensee MDPI, Basel, Switzerland. This article is an open access article distributed under the terms and conditions of the Creative Commons Attribution (CC BY) license (https: / / creativecommons.org/ licenses/by/4.0/).
1 Department of Clinical and Biological Sciences, University of Turin, Regione Gonzole 10, 10043 Orbassano, Italy; claudia.penna@unito.it (C.P.); stefano.comita@unito.it (S.C.); pasquale.pagliaro@unito.it (P.P.)

2 Department of Medical Sciences, University of Turin, Corso Dogliotti 14, 10126 Turin, Italy; saveria.femmino@unito.it (S.F.); marta.tapparo@unito.it (M.T.); tatiana.lopatina@unito.it (T.L.); francesco.ravera@edu.unito.it (F.R.)

3 Department of Biological Science, University of Bergen, Thormohlensgt 55, 5020 Bergen, Norway; kari.fladmark@uib.no

4 Uni-Astiss, Polo Universitario Rita Levi Montalcini, 14100 Asti, Italy; giuseppe.alloatti@unito.it

5 Department of Life, Health and Environmental Sciences, University of L'Aquila, Via Vetoio-Coppito 2, 67100 L'Aquila, Italy; ilaria.giusti@univaq.it (I.G.); vincenza.dolo@univaq.it (V.D.)

* Correspondence: giovanni.camussi@unito.it (G.C.); mariafelice.brizzi@unito.it (M.F.B.)

$+\quad$ C.P. and S.F. Contributed Equally.

$\ddagger \quad$ P.P. and M.F.B. Share Senior Authorship.

\begin{abstract}
The biological relevance of extracellular vesicles (EV) released in an ischemia/reperfusion setting is still unclear. We hypothesized that the inflammatory microenvironment prevents cardioprotection mediated by endothelial cell (EC)-derived extracellular vesicles. The effects of naïve EC-derived EV (eEV) or eEV released in response to interleukin-3 (IL-3) (eEV-IL-3) were evaluated in cardiomyoblasts $(\mathrm{H} 9 \mathrm{c} 2)$ and rat hearts. In transwell assay, eEV protected the $\mathrm{H} 9 \mathrm{c} 2$ exposed to hypoxia/reoxygenation (H/R) more efficiently than eEV-IL-3. Conversely, only eEV directly protected $\mathrm{H} 9 \mathrm{c} 2$ cells to $\mathrm{H} / \mathrm{R}$-induced damage. Consistent with this latter observation, eEV, but not eEV-IL-3, exerted beneficial effects in the whole heart. Protein profiles of eEV and eEV-IL-3, established using label-free mass spectrometry, demonstrated that IL-3 drives changes in eEV-IL-3 protein cargo. Gene ontology analysis revealed that both eEV and eEV-IL-3 were equipped with full cardioprotective machinery, including the Nitric Oxide Signaling in the Cardiovascular System. eEV-IL-3 were also enriched in the endothelial-nitric oxide-synthase (eNOS)-antagonist caveolin-1 and proteins related to the inflammatory response. In vitro and ex vivo experiments demonstrated that a functional Mitogen-Activated Protein Kinase Kinase (MEK1/2)/eNOS/guanylyl-cyclase (GC) pathway is required for eEV-mediated cardioprotection. Consistently, eEV were found enriched in MEK1/2 and able to induce the expression of B-cell-lymphoma-2 (Bcl-2) and the phosphorylation of eNOS in vitro. We conclude that an inflammatory microenvironment containing IL-3 changes the eEV cargo and impairs eEV cardioprotective action.
\end{abstract}

Keywords: cardiac damage; ischemia/reperfusion injury; endothelial-derived extracellular vesicles; inflammatory cytokines; interleukin 3

\section{Introduction}

Cardiovascular diseases (CVDs), and in particular myocardial infarction (MI), are the most frequent causes of morbidity and mortality worldwide [1]. Primary percutaneous coronary intervention (PPCI) remains the most appropriate approach to restore the coronary 
blood flow and improve patients' outcomes [2]. However, PPCI does not completely prevent patient overall mortality rate [3]. This implies that to limit myocardial ischemia/reperfusion (I/R) injury and improve clinical outcomes, new strategies should be investigated [4]. Many agents, acting at different sites of the damaging cascade, have been shown to reduce the infarct size in different I/R preclinical models [5]. However, these therapeutic options are still far from being approved in clinic [6]. The most relevant mechanisms accounting for the I/R injury include ATP depletion, the production of reactive oxygen species (ROS) and reactive nitrogen species (RNS), alterations of cell membrane permeability, loss of intracellular calcium homeostasis, and mitochondrial damage [7,8]. However, along with the direct effects of $I / R$, systemic inflammation via the release of pro-inflammatory cytokines can drive damaging cues to both vessels and cardiomyocytes $[9,10]$. It is worth noting that IL-3, originally described as a hematopoietic growth factor [11], has been recognized from among the inflammatory mediators [12] released by the activated T-lymphocytes into sites of inflammation [13]. Moreover, IL-3 induces endothelial cell (EC) activation and provides angiogenic cues both directly [14] and via paracrine mechanisms involving the release of extracellular vesicles (EV) [15]. These dual pro-inflammatory and proangiogenic IL-3 actions drove us to select IL-3 from among potential paracrine inflammatory mediators.

EV have recently been recognized as one of the most relevant mechanisms of cellto-cell communication both at local and remote sites $[15,16]$. Indeed, EV contribute to several pathophysiological processes including angiogenesis, coagulation, tissue repair, and inflammation [16-18]. However, in models of I/R injury, the role of EV is still a matter of debate, since both beneficial and detrimental effects have been described [19]. Circulating EV collected after preconditioning protocols have been shown to significantly reduce I/R injury $[20,21]$. Yet, the activation of oxidative processes and the induction of cardiomyocyte apoptosis have also been reported upon treatment with EV released by EC $(\mathrm{eEV})$ subjected to I/R. Moreover, increased local inflammation has been reported upon treatment with eEV released during acute myocardial infarction [22,23]. Additionally, intracardiac fibroblasts and macrophages contribute to the local inflammatory response during myocardial I/R injury [24-26]. These data suggest that the release of EV and the activation of the inflammatory response in the ischemic microenvironment may contribute to establish the degree of the overall damage. Therefore, the impact on the local response associated to I/R injury of naïve eEV and eEV released in an inflammatory setting containing IL-3 (eEV-IL-3) was evaluated using the in vitro and ex vivo myocardial I/R models. Moreover, to provide insight on the eEV and eEV-IL-3 mechanism of action, proteomic analysis was performed. Given the endothelial nature of $\mathrm{EV}$, the role of the endothelial nitric oxide (NO) synthase (eNOS), the guanylyl cyclase (GC), and the Mitogen-Activated Protein KinaseExtracellular Signal-Regulated Kinase (MEK1/2) pathways [27,28] have been investigated both in in vitro and in ex vivo models.

\section{Materials and Methods}

2.1. Culture of Human EC (Human Microvascular Endothelial Cell Line-1, HMEC-1 and Human Umbilical Vein Cells, HUVEC), and Rat Embryonic Cardiac Myoblasts (H9c2)

HMEC-1, HUVEC, and rat-derived H9c2 cells were obtained from the American Type Culture Collection (ATCC; Manassas, VA, USA). HMEC-1 were grown in MCDB 131 Medium supplemented with $10 \%$ fetal bovine serum (FBS), $10 \mathrm{ng} / \mathrm{mL}$ of epidermal growth factor, $1 \mu \mathrm{g} / \mathrm{mL}$ of hydrocortisone, $2 \mathrm{mM}$ glutamine, and $1 \%(\mathrm{v} / \mathrm{v})$ streptomycin/penicillin at $37{ }^{\circ} \mathrm{C}$ and $5 \% \mathrm{CO}_{2}$, while Human Umbilical Vein Cells (HUVEC) were cultured in M199 plus 10\% (v/v) bovine calf serum (BCS), $2 \%(\mathrm{v} / \mathrm{v})$ of streptomycin/penicillin and $5 \mathrm{ng} / \mathrm{mL}$ of bFGF. H9c2 cells were grown at $37^{\circ} \mathrm{C}$ and $5 \% \mathrm{CO}_{2}$ in Dulbecco's modified Eagle's medium nutrient mixture F-12 HAM (DMEM-F12) and supplemented with 10\% fetal bovine serum (FBS) and 1\% (v/v) streptomycin/penicillin [29]. 


\subsection{EC-EV Isolation and Characterization}

To collect EV, overnight starved HUVEC were either left untreated or treated with IL-3 $(10 \mathrm{ng} / \mathrm{mL})$ or anti-IL-3R $\alpha$ neutralizing antibody (R\&D Systems, Minneapolis, MN, USA) as previously described [15]. The conditioned medium (40 pooled HUVEC cultures/EV group) was centrifuged for $30 \mathrm{~min}$ at $3000 \times g$ to remove cell debris and apoptotic bodies and then submitted to microfiltration with $0.22 \mu \mathrm{m}$ filters (MF-Millipore) to remove larger vesicles. Then, the supernatant was ultracentrifuged for $2 \mathrm{~h}$ at $100,000 \times g, 4{ }^{\circ} \mathrm{C}$, using the Beckman Coulter Optima L-100K Ultracentrifuge with the rotor type 45 Ti 45,000 rpm. The pellet of EV obtained was resuspended in DMEM supplemented with 1\% DMSO. Then, the EV suspension (from 40 different sample collection) was collected as 3 individual pools and stored at $-80{ }^{\circ} \mathrm{C}$ until further use. In selected experiments, 8 pooled HUVEC cultures were used to recover anti-IL-3R-eEV. EV were analyzed using NTA analysis, the NanoSight NS300 system (Malvern Instruments, Ltd., Malvern, PA, USA), and FACS analysis. EV flow cytometry analysis was performed using the MACSPlex Exosome Kit (human, Miltenyi Biotec Bologna, Italy), following the manufacturer's protocol [30]. Each sample was analyzed using a CytoFLEX Flow Cytometer (Beckman Coulter, Brea, CA, US). CytExpert Software (Beckman Coulter, Brea, CA, USA) was used to analyze flow cytometric data. For EV quantification (particle number), NTA was used.

\subsection{Transmission Electron Microscopy}

After collection, EV were resuspended in PBS and properly diluted. Therefore, the samples were incubated for 5 min onto carbon-coated copper grids, 200 mesh (Electron Microscopy Sciences, Hatfield, PA, USA) at room temperature in a humidified chamber. The EV adsorbed on the grids were fixed (2\% glutaraldehyde diluted in PBS) (Electron Microscopy Sciences, Hatfield, PA, USA) for $10 \mathrm{~min}$, diluted in PBS for $10 \mathrm{~min}$, washed 3 times in Milli-Q water, negative stained with $2 \%$ phosphotungstic acid, brought to $\mathrm{pH} 7.0$ with $\mathrm{NaOH}$, and air dried. Grids were observed using a Philips CM100 (Eindhoven, The Netherland) equipped with a detector at $80 \mathrm{kV}, 64000 \mathrm{X}$ [31].

\subsection{Hypoxia/Reoxygenation (H/R) Protocol}

For the in-vitro hypoxia-reoxygenation (H/R) experiments, H9c2 cells were serumstarved (in exosome depleted FBS $2 \%$ ) for $2 \mathrm{~h}$. Cells were pretreated with different $\mathrm{eEV}$, eEV-IL-3 number $\left(7 \times 10^{3}, 1 \times 10^{4}\right.$ and $1 \times 10^{6} \mathrm{EV} /$ cell $)$ or IL-3 $(10 \mathrm{ng} / \mathrm{mL})$ for $2 \mathrm{~h}$ and then exposed to hypoxia $\left(1 \% \mathrm{O}_{2}, 5 \% \mathrm{CO}_{2}\right)$ for additional $2 \mathrm{~h}$ in the presence of eEV, eEV-IL-3, or IL-3 and subsequently reoxygenated $\left(21 \% \mathrm{O}_{2}\right.$ and $\left.5 \% \mathrm{CO}_{2}\right)$ for $1 \mathrm{~h}$. For HMEC- 1 and $\mathrm{H} 9 \mathrm{c} 2$, co-culture $5 \times 10^{3}$ HMEC-1 cells were seeded into each of Millicell 24-well plate inserts with $0.4 \mu \mathrm{m}$ pores (Millipore, Milan, Italy) while $3 \times 10^{4} \mathrm{H} 9 \mathrm{c} 2$ were seeded into the lower wells. Cells were allowed to attach for $24 \mathrm{~h}$ and serum-starved for additional $24 \mathrm{~h}$. HMEC-1 were treated or not with eEV, eEV-IL-3, or IL-3 $\left(10 \times 10^{4} /\right.$ cell for eEV and eEV-IL-3 (found effective in preliminary dose response curve) and $50 / \mathrm{ng} / \mathrm{mL}$ for IL-3) for $2 \mathrm{~h}$, exposed to hypoxia $\left(1 \% \mathrm{O}_{2}, 5 \% \mathrm{CO}_{2}\right)$ for an additional $2 \mathrm{~h}$, and subsequently re-oxygenated ( $21 \%$ $\mathrm{O}_{2}$ and $5 \% \mathrm{CO}_{2}$ ) for $1 \mathrm{~h}$. H9c2 viability was evaluated with 3-(4,5-dimethylthiazol-2-yl)2,5-diphenyltetrazolium bromide (MTT) assay [29]. In selected experiments the aboveindicated stimuli were also used in combination with U0126 $(15 \mu \mathrm{M})$, L-NNA $(100 \mu \mathrm{M})$ or ODQ $(100 \mu \mathrm{M})$ [32-34].

\subsection{MTT Assay}

At the end of the $\mathrm{H} / \mathrm{R}$ protocol, cell viability was assessed using the 3-(4,5-dimethylthiazol -2-yl)-2,5-diphenyltetrazolium bromide (MTT) kit (10 $\mu \mathrm{L} /$ well) as indicated by manufacturers. Briefly, after $2 \mathrm{~h}$ incubation at $37^{\circ} \mathrm{C}$, dimethyl sulfoxide (DMSO) was added. The plates were read at $570 \mathrm{~nm}$ to obtain the optical density values [29]. 


\subsection{Label-Free Mass Spectrometry Analysis}

Protein $(20 \mu \mathrm{g})$ denaturation, reduction, and trypsination and peptide up-concentration and desalting were performed as in [35]. Tryptic peptides were dissolved in 5\% ACN, $0.1 \%$ TFA were injected into an Ultimate 3000 RSLC system (Thermo Scientific, Sunnyvale, CA, USA) connected online to a Q-Excative HF mass spectrometer (Thermo Scientific, Bremen, Germany) and equipped with EASY-spray nano-electrospray ion source (Thermo Scientific, Monza, Italy).

Peptide trapping and desalting in the nano-LC were as described in [35]. Peptide separation (120 $\mathrm{min}$ ) was also as in [35] apart from the following change in settings: (1) solvent A and B were $0.1 \%$ TFA (v/v) in water and $100 \%$ ACN respectively, (2) gradient composition was $5 \%$ B during trapping ( $5 \mathrm{~min}$ ) followed by $5-8 \%$ B over $0.5 \mathrm{~min}, 8-35 \% \mathrm{~B}$ for the next $134.5 \mathrm{~min}$, and $35-90 \%$ B over $15 \mathrm{~min}$. MS spectra were acquired as in [35] apart from a change in intensity threshold to $5 \mathrm{e} 4$ and resolution to $\mathrm{R}=60,000$. The raw files were searched in MaxQuant (version 1.5.2.8, Heidelberg, Germany) against a human reviewed database from UniProt (downloaded November 2015, Cambridge, UK), The following search parameters were used; carbamidomethyl (Cys) as fixed modification, oxidation (Met), phosphorylation (STY), and acetyl (Protein N-terminal) as variable modifications. We allowed for two miss cleavages of trypsin, $20 \mathrm{ppm}$ for precursors, and 0.6 Da for fragment ion mass tolerance, and a false discovery rate (FDR) at $1 \%$. Only unmodified and two unique + razor peptides were used for quantifications. Perseus (1.5.2.6, Heidelberg, Germany) was used for further analysis. Proteins identified by site, reverse hit, and potential contaminants were removed. The protein list was further reduced by only keeping proteins with at least 3 out of 6 valid values. The LFQ intensity values were log2 transformed, and proteins were considered significant if they passed the two sample t-test with the following settings; $S 0=2$ and FDR 0.01. $p$-values were given as Log10 value.

\subsection{Protein Pathway Analysis}

A list of unique proteins identified by MS/MS spectra and significantly expressed was taken into consideration to performed GO analysis and pathway enrichment analysis. Gene ontology analysis was performed with Funrich V3 software looking at molecular function and cellular process category [36]. Pathway enrichment analysis and disease association analysis were performed using Ingenuity Pathway Analysis (IPA) software (Qiagen, Milan, Italy).

\subsection{Animals}

Male Wistar rats (4-5 months old, body weight $400-450$ g, Harlan Laboratories, Udine, Italy) were used for the assessment of cardio-protection as below specified in the I/R studies. Rats received human care according to the European Directive 2010/63/EU on the protection of animals used for scientific purposes. The Italian National Institute of Health Guide for the Care and Use of Laboratory Animals (protocol no: E669C.N.OVL) approved the animal protocols. Animals were housed under controlled conditions with free access to tap water and to standard rat diet.

\subsection{Ischemia/Reperfusion (I/R) Studies}

Rats were anesthetized and heparinized (800 U/100 g b.w., i.m.). Depth anesthesia was assessed by the absence of withdraw reflexes. Then, hearts were quickly excised, placed in ice-cold buffer solution, cleaned up, and weighed. Hearts were attached to the perfusion apparatus and perfused with oxygenated Krebs-Henseleit buffer solution (KHS) through a cannula inserted into the ascending aorta. The KHS contained $(\mathrm{mM}): 127 \mathrm{NaCl}, 5.1 \mathrm{KCl}$, 17.7 $\mathrm{NaHCO}_{3}, 1.26 \mathrm{MgCl}_{4}, 1.5 \mathrm{CaCl}_{2}, 11 \mathrm{D}$-glucose $\left(\mathrm{pH} 7.4 ; 37^{\circ} \mathrm{C} ; 95 \% \mathrm{O}_{2} / 5 \% \mathrm{CO}_{2}\right.$ ). The hearts were located in a temperature-controlled chamber $\left(37^{\circ} \mathrm{C}\right)$. Cardiac preparations were perfused in constant-flow mode. In order to assess the cardiac preparation, coronary perfusion and left ventricular pressure were monitored during the entire experiments [37]. 


\subsection{Experimental Groups}

To verify the protective effect of eEV and eEV-IL-3, the hearts were assigned to one of the experimental groups below described. In all groups, except for SHAM, the hearts were subject to I/R protocol consisting of $30 \mathrm{~min}$ stabilization and $30 \mathrm{~min}$ of norm-thermic global ischemia; then, the ischemia was followed by $60 \mathrm{~min}$ reperfusion. eEV and eEV-IL3 doses were selected based on our preliminary experiments (data not shown).

(1) SHAM $(n=3)$ only KHS has been infused.

(2) I/R group $(n=8)$ after stabilization, only I/R protocol was performed [38].

(3) eEV group $(n=5)$, eEV $\left(1 \times 10^{9} / \mathrm{mL}\right.$ final concentration) were diluted in KHS and infused into the hearts, through a collateral line for $10 \mathrm{~min}$, then the hearts underwent $\mathrm{I} / \mathrm{R}$ protocol.

(4) eEV-IL-3 group $(n=5)$ eEV-IL-3 $\left(1 \times 10^{9} / \mathrm{mL}\right.$ final concentration) were diluted in KHS and infused into the heart, through a collateral line for $10 \mathrm{~min}$, then hearts underwent $\mathrm{I} / \mathrm{R}$ protocol.

(5) IL-3 group $(n=5)$ IL-3 $(50 \mathrm{ng} / \mathrm{mL})$ [14] was diluted in KHS and infused into the heart, through a collateral line for $10 \mathrm{~min}$, then the hearts underwent I/R protocol.

(6) Triton X-100 $(n=3)$, in these hearts, the endothelium was made dysfunctional by a $0.1 \mathrm{~mL}$ Triton $\mathrm{X}-100(5 \mu \mathrm{L} / \mathrm{mL})$ injection $[39,40]$.

(7) eEV after Triton X-100 $(n=3)$, in these hearts, eEV $\left(1 \times 10^{9} / \mathrm{mL}\right.$ final concentration) infusion was performed after the endothelium was made dysfunctional by a $0.1 \mathrm{~mL}$ Triton X-100 $(5 \mu \mathrm{L} / \mathrm{mL})$ injection $[39,40]$.

(8) eEV+L-NNA group $(n=3)$, the eNOS inhibitor $\mathrm{N}$ omega-nitro-L-arginine (LNNA, $100 \mu \mathrm{M}$ ) was used to assess the involvement of eNOS enzyme in eEV-induced cardioprotection $\left(1 \times 10^{9} / \mathrm{mL}\right.$ final concentration) [41].

(9) eEV+U0126 group $(n=3)$, the MEK1/2 blocker 1,4-Diamino-2,3-dicyano-1,4-bis(2 aminophenylthio) butadiene (U0126: $60 \mu \mathrm{M}$ ) was used to ascertain the involvement of MEK1/2 in eEV- $\left(1 \times 10^{9} / \mathrm{mL}\right.$ final concentration $)$ induced cardioprotection [38].

(10) eEV+ODQ group $(n=3)$, the GC blocker $1 \mathrm{H}-(1,2,4)$ oxadiazolo(4,3-a)quinoxalin-1one (ODQ; $10 \mu \mathrm{M})$ was used to ascertain the involvement of the GC enzyme in eEV$\left(1 \times 10^{9} / \mathrm{mL}\right.$ final concentration) induced cardioprotection [37].

\subsection{Infarct Size Assessment}

The extent of infarct size was evaluated using a gravimetric method in a blind manner. At the end of each experiment, the hearts were quickly removed from the perfusion apparatus and the left ventricle was dissected into $2-3 \mathrm{~mm}$ circumferential slices. After $20 \mathrm{~min}$ of incubation at $37^{\circ} \mathrm{C}$ in a $0.1 \%$ solution of nitro-blue tetrazolium in phosphate buffer, the colored vital tissue was carefully separated from the non-stained necrotic tissue and weighed. Since ischemia is global, the entire total left ventricular mass was considered as the area at risk, and the necrotic mass was expressed as percentage of the total ventricle mass [38].

\subsection{Western Blot Analysis}

eEV and eEV-IL-3 were lysed in lysis buffer (RIPA buffer with proteinase inhibitors). Starting from the same EV particle number, protein samples were quantified by the Bradford method before performing Western blot ( $50 \mu \mathrm{g}$ proteins/each sample were loaded). Anti-CD63, anti-CD81, antiHSP90, anti-GM130, anti-Bcl-2 (Abcam, Milan, Italy), antiMEK1/2, (Cell Signaling, Danvers, MA, USA), anti-CD29, anti-caveolin-1, anti-p-eNOSser1177 (Invitrogen, Carlsbad, CA, USA), and anti-vinculin (Millipore, Milan, Italy) antibodies were used as primary antibodies. Appropriate HRP-conjugated secondary antibodies (BioRad, Milan, Italy) were used, and proteins were detected with Clarity Western ECL substrate (BioRad, Milan, Italy). Image Lab Software (BioRad Milan, Italy) instrument was used for densitometric analysis. Data are expressed as arbitrary unit. Ponceaus-staining has been used as input (EV protein content normalization). 


\subsection{Chemicals}

The sources of the specific antibodies are shown in the different sections. If not differently specified, the other reagents were obtained from Sigma (St. Louis, MO, USA).

\subsection{Statistical Analysis}

Data are expressed as mean \pm SEM. Statistical analysis was performed as follows: $t$ test was used for the comparison between two groups, while one-way ANOVA was used for comparison between $\geq 3$ groups followed by Student's $t$-test or the Newman-Keuls multiple-range test depending on the experiments. $p$-value $\leq 0.05$ was considered as significant. Graph Pad Prism version 8.2.1 (Graph Pad Software, Inc, USA) was used for statistical analyses.

\section{Results}

\section{1. eEV and eEV-IL-3 Have Similar Size and Surface Markers}

eEV and eEV-IL-3 were first recovered from naïve Human Umbilical Vein EC (HUVEC) and HUVEC exposed to IL-3 and subjected to NanoSight, transmission electron microscopy (TEM) and FACS analyses. Since cells may undergo apoptosis or autophagy in the absence of serum and release apoptotic bodies, EV obtained after filtration were used. As previously reported [15], IL-3 treatment boosts the release of EV by HUVEC; however, no difference between eEV and eEV-IL-3 size was detected by Nanosight $(193 \pm 4.3 \mathrm{~nm}$ and $192.4 \pm 3.5 \mathrm{~nm}$ respectively) and TEM (Figure 1A). As expected, endothelial markers (CD31, CD146, and CD105) were found highly expressed in both eEV and eEV-IL-3 (Figure 1B). Western blot analysis was performed to validate the expression of exosomal markers (Figure 1B). GM130 protein served as a negative marker of EV (Figure 1B). Moreover, FACS analysis, using the MACSPlex exosome kit, revealed a similar pattern of surface marker expression (Figure 1C). Endothelial and exosomal markers identified in proteome analysis are reported in Figure 1D.

A)

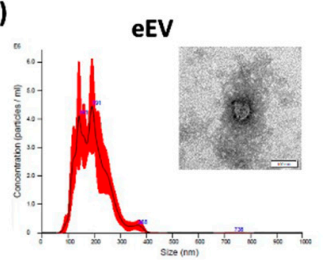

C)

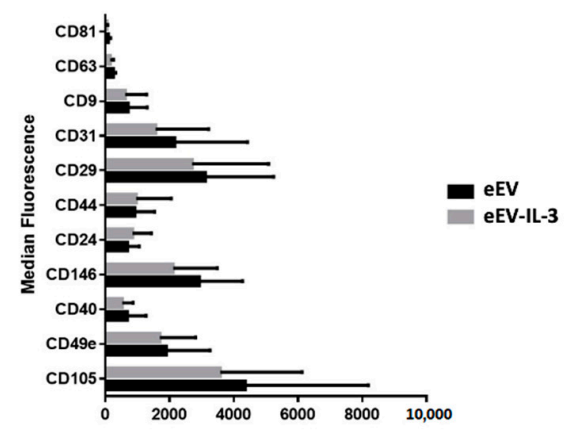

B)

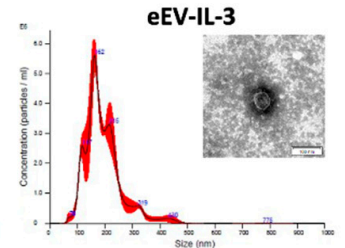

D)

\begin{tabular}{|c|c|c|c|c|c|}
\hline & Protein names & $\begin{array}{c}\text { Gene } \\
\text { names }\end{array}$ & $\begin{array}{c}\text { Mol. } \\
\text { weight } \\
\text { [kDa] }\end{array}$ & $\begin{array}{c}\text { LFQ } \\
\text { intensity } \\
\text { Mean eEV }\end{array}$ & $\begin{array}{l}\text { LFQ intensity } \\
\text { Mean eEV-IL-3 }\end{array}$ \\
\hline \multirow{6}{*}{$\begin{array}{l}\text { Exosomal } \\
\text { markers }\end{array}$} & CD81 antigen & CD81 & 25.809 & 25.78 & 27.40 \\
\hline & CD63 antigen & CD63 & 25.636 & N/A & 25.17 \\
\hline & CD9 antigen & CD9 & 25.416 & 26.88 & 28.22 \\
\hline & $\begin{array}{l}\text { Integrin beta-1 } \\
\text { (CD29) }\end{array}$ & ITGB1 & 88.414 & 28.66 & 31.44 \\
\hline & $\begin{array}{c}\text { Integrin alpha-5 } \\
\text { (CD49e) }\end{array}$ & ITGAS & 114.54 & 26.89 & 29.60 \\
\hline & CD44 antigen & CD44 & 81.537 & 23.12 & 23.22 \\
\hline \multirow{4}{*}{$\begin{array}{c}\text { Endothelial } \\
\text { markers }\end{array}$} & $\begin{array}{l}\text { Platelet endothelial } \\
\text { cell adhesion } \\
\text { molecule (CD31) }\end{array}$ & PECAM1 & 82.535 & 27.57 & 30.60 \\
\hline & Endoglin (CD105) & ENG & 70.577 & 26.50 & 28.80 \\
\hline & $\begin{array}{l}\text { Tumor necrosis factor } \\
\text { receptor superfamily } \\
\text { member } 5 \text { (CD40) }\end{array}$ & CD40 & 30.619 & N/A & 24.83 \\
\hline & $\begin{array}{c}\text { Cell surface } \\
\text { glycoprotein MUC18 } \\
\text { (CD146) }\end{array}$ & MCAM & 71.607 & 26.99 & 29.03 \\
\hline
\end{tabular}

Figure 1. Endothelial cell-derived extracellular vesicles (eEV) and eEV released in response to interleukin-3 (eEV-IL-3) characterization. (A) Representative images of NanoSight analyses and TEM performed on eEV and eEV-IL-3. (B) Western blot. Representative images of exosomal markers, CD29, CD63, and CD81, expressed in eEV and eEV-IL-3. GM130 protein expression served as a negative EV marker. Indeed, it was expressed only in the cell extract (Ctrl Human Umbilical Vein Cells (HUVEC)). (C) eEV and eEV-IL-3 characterization with MACSPlex Exosome Kit. (D) The table reports the expression of eEV and eEV-IL-3 exosomal and endothelial markers provided by mass spectrometry. 
3.2. Both eEV and eEV-IL-3 Induce Protection in a Simulated In Situ Condition, While Only eEV Directly Trigger Cardioprotective Signals

First, the biological effects exerted by eEV and eEV-IL-3 were evaluated on primary cultures of cardiomyoblasts (H9c2) exposed to the in vitro model of hypoxia/reoxygenation $(\mathrm{H} / \mathrm{R})$ (Figure 2A). IL-3 served as an internal control. As shown in Figure 2B,C, H9c2 cell death was prevented in response to eEV, but not eEV-IL-3 or IL-3. In order to mimic the in vivo condition, experiments were also performed in transwells. To this end, HMEC-1 were seeded in the upper chamber and pre-conditioned for $2 \mathrm{~h}$ with eEV and eEV-IL-3. $\mathrm{H} 9 \mathrm{c} 2$ were seeded in the lower chamber. Then, the cells were subjected to the H/R protocol (Figure 2A,D) and H9c2 viability was analyzed. As shown in Figure 2E, eEV significantly improved cell viability, not only with respect to untreated hypoxic cells (NONE), but also when compared to normoxic conditions (CTRL N). A slight increase of H9c2e cell viability was also detected upon eEV-IL-3 treatment. IL-3 alone had no protective effects (Figure 2E).

A)

\begin{tabular}{|c|c|c|}
\hline \multicolumn{3}{|c|}{ DMEM $2 \%$ FBS } \\
\hline \multicolumn{3}{|c|}{ Hypoxia/Reoxygenation (Group 2) } \\
\hline DMEM $2 \%$ FBS & Hypoxia & Reoxygenation \\
\hline \multicolumn{3}{|c|}{ eEV or eEV-IL-3 or IL-3 (Group 3-4-5) } \\
\hline $\begin{array}{l}\text { eEV or eEV-IL-3 or IL-3 } \\
\text { in DMEM } 2 \% \text { FBS }\end{array}$ & $\begin{array}{c}\text { Hypoxia and } \\
\text { eEV or eEV-IL-3 or IL-3 }\end{array}$ & Reoxygenation \\
\hline 2 hours & 2 hours & 1 hour \\
\hline
\end{tabular}

B)

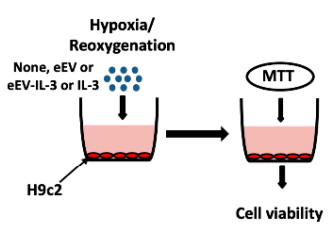

C)

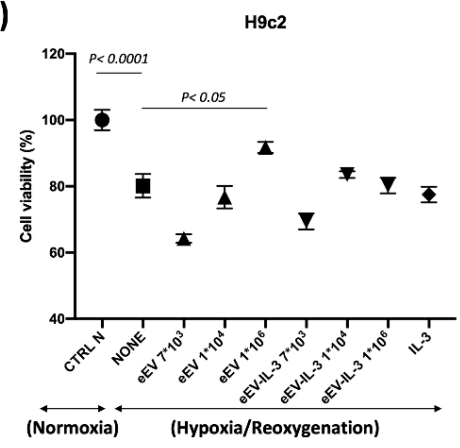

D)

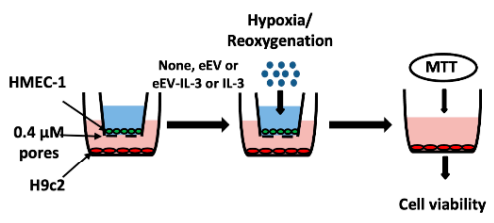

E)

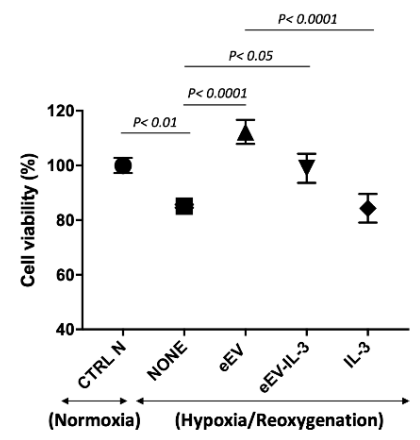

Figure 2. eEV, unlike eEV-IL-3, directly protect $\mathrm{H} 9 \mathrm{c} 2$ cells from hypoxia/reoxygenation $(\mathrm{H} / \mathrm{R})$ injury. (A) Timeline of the in vitro protocol. Protocols of hypoxia (black boxes) and reoxygenation (white boxes) of H9c2 cells and EC. eEV-IL-3, eEV, or IL-3 were given for $2 \mathrm{~h}$ before hypoxia and during hypoxia. Cells were subjected to reoxygenation for $1 \mathrm{~h}$. (B) Representative image of H9c2 cell treatment. (C) Cell viability of $\mathrm{H} 9 \mathrm{c} 2$ cells exposed to normoxia (N) and hypoxia/reoxygenation $(\mathrm{H} / \mathrm{R})$ conditions in the presence of the indicated number of eEV and eEV-IL-3/cell. Data are presented as percentage variation with respect to mean value of cell count in normoxia (CTRL N) $(n=3) . p<0.0001$ CTRL N vs. NONE; $p<0.05$ NONE vs. eEV $1 \times 10^{6}$. (D) Representative image of trans-well assay of Human Microvascular Endothelial Cell Line-1 (HMEC-1) cells seeded in the upper well and H9c2 cells in the lower well. HMEC-1 cells treated or not with eEV or eEV-IL-3 were subjected to $\mathrm{H} / \mathrm{R}$ conditions. 3-(4,5-Dimethylthiazol-2-yl)-2,5-diphenyltetrazolium bromide (MTT) assay was performed on $\mathrm{H} 9 \mathrm{c} 2$ cells. (E) Cell viability of $\mathrm{H} 9 \mathrm{c} 2$ cells exposed to $\mathrm{H} / \mathrm{R}$ conditions $(n=4) . p<0.01$ CTRL N vs. NONE and eEV; $p<0.0001$ NONE vs. eEV and eEV vs. IL-3. Data were normalized to the mean value of normoxic control (CTRL N). 


\section{3. eEV, But Not eEV-IL-3, Exert Endothelial-Dependent Protection against I/R in the Whole Heart}

Since the infarct size (as percentage of AAR) is considered a clearer indicator of I/R injury, AAR was evaluated in our experimental groups [42]. Figure 3A shows the ex vivo $\mathrm{I} / \mathrm{R}$ protocol and treatment $\left(1 \times 10^{9} \mathrm{eEV}\right.$ or eEV-IL-3) we selected based on our preliminary studies (data not shown). The hearts infused with Krebs-Henseleit solution (KHS) (SHAM) served as internal control. In the I/R control group, the hearts developed infarction, which corresponded to $60 \pm 2 \%$ of area at risk (AAR). Of note, the infarct size was $43 \pm 3 \%$ of AAR in the hearts pretreated with eEV (Figure 3B,C; $p<0.001 \mathrm{eEV}$ vs. I/R group). This protective effect was not observed in the hearts that have been exposed to eEV-IL-3 or IL-3 (Figure 3B,C). Indeed, an infarct size (61 $\pm 3 \%$ of AAR for eEV-IL-3, and $72 \pm 5 \%$ of AAR for IL-3; Figure 3B,C) similar to the control group was noticed in these groups. To evaluate whether the integrity of the EC monolayer could impact on tissue outcomes, ex vivo experiments were extended to the hearts, which have been pretreated with Triton X100 to induce EC damage. As shown in Figure 3B,C, treatment with eEV was no more effective upon EC damage.

A)

\begin{tabular}{|c|c|c|c|}
\hline Stabilization & \multicolumn{3}{|c|}{ KHS } \\
\hline \multicolumn{4}{|c|}{ Ischemia/Reperfusion (Group 2) } \\
\hline Stabilization & KHS & Ischemia & Reperfusion \\
\hline \multicolumn{4}{|c|}{ eEV; eEV-IL-3; IL-3 (Group 3-4-5) } \\
\hline Stabilization & $\begin{array}{l}\text { EV or } \\
\mathrm{IL}-3\end{array}$ & Ischemia & Reperfusion \\
\hline \multicolumn{4}{|c|}{ Triton; eEV + Triton (Group 6-7) } \\
\hline Stabilization & $\begin{array}{l}\text { EV or } \\
\text { KHS }\end{array}$ & Ischemia & Reperfusion \\
\hline & & & \\
\hline $30 \mathrm{~min}$ & $10 \mathrm{~min}$ & $30 \mathrm{~min}$ & $60 \mathrm{~min}$ \\
\hline
\end{tabular}

B)

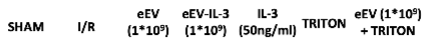

C)
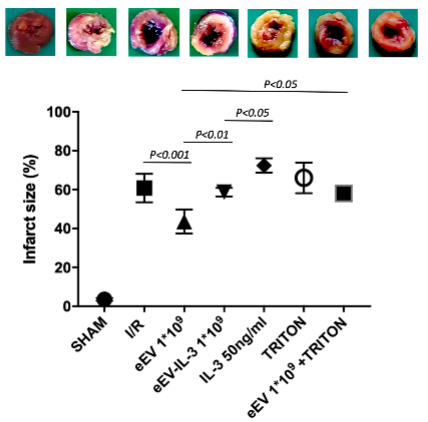

Figure 3. eEV, but not eEV-IL-3, protects isolated rat hearts from I/R-induced damage. (A) Timeline of ex vivo protocol. Protocols of ischemia (black boxes) and reperfusion (white boxes) in isolated rat hearts. After stabilization (white boxes), Krebs-Henseleit buffer solution (KHS) was infused alone (I/R) or with eEV, eEV-IL-3, or IL-3. eEV $\left(1 \times 10^{9}\right)$, eEV-IL-3 $\left(1 \times 10^{9}\right)$, or IL-3 $(50 \mathrm{ng} / \mathrm{mL})$ given for 10 min before ischemia, while Triton before KHS or eEV. The KHS-infused hearts not subjected to I/R (SHAM) served as internal control. (B) Representative images of the heart slices, obtained after NBT staining. The images correspond to SHAM, I/R, eEV $1 \times 10^{9}$, eEV-IL-3 $1 \times 10^{9}$, IL-3 $(50 \mathrm{ng} / \mathrm{mL})$, and TRITON eEV $1 \times 10^{9}+$ TRITON, respectively. (C) Infarct size in isolated rat hearts exposed to $30 \mathrm{~min}$ of ischemia plus $60 \mathrm{~min}$ of reperfusion, pretreated or not with eEV, eEV-IL-3, or IL-3 $10 \mathrm{~min}$ before inducing ischemia. The amount of necrotic tissue measured after I/R protocol is reported as percentage of the left ventricle mass (LV; \% IS/LV) for I/ R $(n=8)$, eEV $1 \times 10^{9}(n=5)$, eEV-IL-3 $1 \times 10^{9}(n=5)$, IL-3, $50 \mathrm{ng} / \mathrm{mL}(n=5)$, TRITON $(n=3)$ and eEV $1 \times 10^{9}+$ TRITON $(n=3)$. $p<0.05$ eEV vs. TRITON and IL-3 vs. eEV-IL-3; $p<0.01$ eEV vs. eEV-IL-3; $p<0.001$ I/R vs. eEV.

\section{4. eEV Are Enriched in MEK1/2 and HPS90 While eEV-IL-3 in the eNOS Antagonist, Caveolin 1}

To gain further insight into the mechanisms accounting for the ex vivo results, protein profiling of eEV and eEV-IL-3 was performed. Label-free mass spectrometry analysis identified a total of 2077 proteins (Figure 4A). Of these, 736 proteins met the criteria for further statistical analysis based on the identification of two or more unique peptides. 
Of these, 651 significant proteins were carried by both eEV and eEV-IL-3, while 54 were carried by eEV-IL-3 and 8 by eEV. Detailed information of the differentially expressed proteins, Student $t$-test statistical analysis, and their respective ratio are reported in Table S1. Ingenuity Pathway Analysis (IPA analysis) demonstrated that most of the proteins carried by eEV and eEV-IL-3 are related to cardiovascular diseases and EC remodeling, and have eNOS as a downstream effector (Tables 1 and 2). These data were validated by analyzing the protein cargo of EV released by EC exposed to IL-3 and pretreated with an anti-IL-3R blocking antibody (anti-IL-3R-eEV) (Figure 4B). As shown in Figure 4B, almost all the upor down-regulated proteins in eEV-IL-3 (vs. eEV) moved back to the eEV content in antiIL-3R-eEV, indicating a specific protein content associated with IL-3 challenge. Pathway analysis of the eEV-IL-3 content showed the enrichment of oxidative stress-related pathways, ER stress, calcium signaling, and VEGF pathway (Table 1). Moreover, among the enriched pathways, Nitric Oxide Signaling in the Cardiovascular System was also found (Figure 4C, Table 1). In particular, a full cardioprotective machinery, including mitochondrial enzymes, control of cell-to-cell contact, cytoskeleton, and proteins involved in NO production was found in eEV-IL-3 (Table 1). Of interest, among proteins differentially expressed, we found an enrichment in the eNOS antagonist, caveolin 1 (Table S1, Figure 4D) in eEV-IL-3. Moreover, we found that eEV-IL-3 was enriched in proteins involved in the activation of the inflammatory response (Table 3 ). In particular, proteins involved in the activation of immune cells, as well as in the IL-8 and nuclear factor kappa B $(\mathrm{NF} K \mathrm{~B})$ pathways were found enriched in eEV-IL-3 (Table 3, Tables S2 and S3). Moreover, proteins classified in the IL-8 and NFKB pathways, and commonly involved in the signaling of different interleukins (IL-2, IL-6, IL-15, IL-17, and others) were also increased in eEV-IL-3 (Table 3, Tables S2 and S3). The only proteins enriched in eEV were MEK1/2 and HSP90 (Table S1, Figure 4D). This suggests that they can contribute to eEV-mediated cardioprotection.
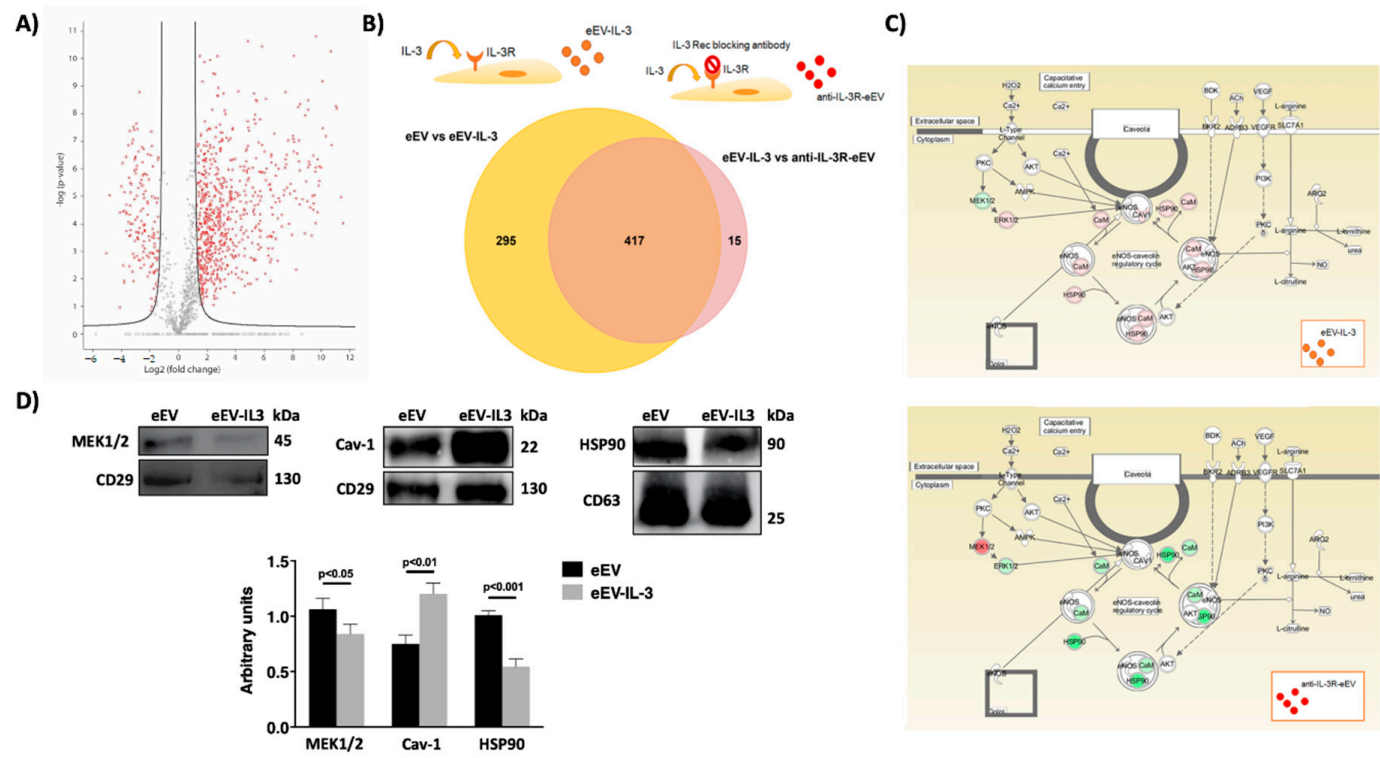

Figure 4. Protein profiling of eEV-IL-3 compared to eEV. (A) Volcano plot of IL-3 induced protein changes by label-free quantitation. Protein expression ratio of eEV-IL3/eEV (log2 scale) in label-free quantitation plotted against the -log of two-sample $t$-test. The lines represent threshold values ( $p$-value 0.05, Fold Change $>2$ ). (B) Venn diagram. Venn diagram shows proteins in eEV-IL-3 compared to eEV (yellow) and anti-IL-3R-eEV (dark pink). Proteins included in the light pink area correspond to proteins only carried by anti-IL-3R-eEV. (C) nitric oxide signaling in the cardiovascular system. In the scheme, proteins modulated in eEV-IL-3 vs. eEV (upper panel) and homecoming in anti-IL-3R-eEV (lower panel) are highlighted. Red corresponds to increased expression; green corresponds to reduced expression. (D) Western blot analysis of eEV and eEV-IL-3. Representative image and relative quantification of MEK1/2 and the negative eNOS regulator, caveolin-1, HSP90 normalized to CD63 and to CD29 respectively (an aliquot of the three pooled samples were used) (MEK1/2: $p<0.05$ eEV vs. eEV-IL-3; Caveolin-1: $p<0.01$ eEV vs. eEV-IL-3; HSP90: $p<0.001$ eEV vs. eEV-IL-3). 
Table 1. List of enriched pathways in which proteins carried by eEV and eEV-IL-3 are involved.

\begin{tabular}{|c|c|}
\hline Ingenuity Canonical Pathways & $-\log (p$-Value $)$ \\
\hline Mitochondrial Dysfunction & 12.9 \\
\hline Caveolar-Mediated Endocytosis Signaling & 11.3 \\
\hline Integrin Signaling & 9.69 \\
\hline Remodeling of Epithelial Adherens Junctions & 9.26 \\
\hline Oxidative Phosphorylation & 8.34 \\
\hline Regulation of eIF4 and p70S6K Signaling & 8.02 \\
\hline Actin Cytoskeleton Signaling & 7.97 \\
\hline Sirtuin Signaling Pathway & 7.33 \\
\hline NRF2-mediated Oxidative Stress Response & 6.14 \\
\hline PI3K/AKT Signaling & 5.95 \\
\hline Regulation of Actin-based Motility by Rho & 5.88 \\
\hline VEGF Signaling & 5.05 \\
\hline p70S6K Signaling & 4.82 \\
\hline Leukocyte Extravasation Signaling & 4.41 \\
\hline Apoptosis Signaling & 3.32 \\
\hline mTOR Signaling & 3.16 \\
\hline Hypoxia Signaling in the Cardiovascular System & 3.14 \\
\hline Clathrin-mediated Endocytosis Signaling & 3.11 \\
\hline Endoplasmic Reticulum Stress Pathway & 2.96 \\
\hline Protein Kinase A Signaling & 2.75 \\
\hline Antigen Presentation Pathway & 2.42 \\
\hline ERK/MAPK Signaling & 2.34 \\
\hline Granulocyte Adhesion and Diapedesis & 2.23 \\
\hline Cardiac Hypertrophy Signaling & 2.05 \\
\hline Role of NFAT in Regulation of the Immune Response & 1.98 \\
\hline CXCR4 Signaling & 1.98 \\
\hline Glutathione Redox Reactions I & 1.93 \\
\hline Acute Phase Response Signaling & 1.92 \\
\hline Calcium Signaling & 1.89 \\
\hline Glutathione-mediated Detoxification & 1.74 \\
\hline Arginine Biosynthesis IV & 1.64 \\
\hline Thioredoxin Pathway & 1.51 \\
\hline Aspartate Degradation II & 1.51 \\
\hline Calcium-induced T Lymphocyte Apoptosis & 1.46 \\
\hline IL-1 Signaling & 1.46 \\
\hline $\mathrm{FcI}^{3}$ Receptor-mediated Phagocytosis in Macrophages and Monocytes & 1.44 \\
\hline Nitric Oxide Signaling in the Cardiovascular System & 1.44 \\
\hline Superoxide Radicals Degradation & 1.39 \\
\hline CCR3 Signaling in Eosinophils & 1.31 \\
\hline
\end{tabular}


Table 2. Diseases and function annotation, performed by IPA analysis, obtained comparing eEV-IL-3 vs. eEV protein cargo.

\begin{tabular}{|c|c|c|c|c|}
\hline Diseases or Functions Annotation & $p$-Value & Predicted Activation State & Activation z-Score & \# Molecules \\
\hline Cell movement of endothelial cells & $4.09 \times 10^{9}$ & Increased & 2.919 & 41 \\
\hline Migration of endothelial cells & $9.55 \times 10^{9}$ & Increased & 2.429 & 38 \\
\hline Vasculogenesis & $2.45 \times 10^{8}$ & Increased & 2.106 & 46 \\
\hline Interaction of endothelial cells & $7.55 \times 10^{8}$ & Increased & 2.587 & 22 \\
\hline Cell death of endothelial cells & $1.21 \times 10^{7}$ & & -1.535 & 21 \\
\hline Binding of endothelial cells & $2.61 \times 10^{7}$ & Increased & 2.402 & 21 \\
\hline Apoptosis of endothelial cells & $6.80 \times 10^{7}$ & & -1.591 & 19 \\
\hline Binding of vascular endothelial cells & $5.83 \times 10^{6}$ & Increased & 2.825 & 15 \\
\hline Adhesion of endothelial cells & $7.63 \times 10^{6}$ & Increased & 2.188 & 15 \\
\hline Apoptosis of vascular endothelial cells & $8.03 \times 10^{6}$ & & -0.969 & 14 \\
\hline Endothelial cell development & $1.60 \times 10^{5}$ & Increased & 2.57 & 30 \\
\hline Movement of vascular endothelial cells & $2.68 \times 10^{5}$ & & 1.976 & 21 \\
\hline Adhesion of vascular endothelial cells & $6.44 \times 10^{5}$ & Increased & 3.087 & 11 \\
\hline Attachment of vascular endothelial cells & $9.14 \times 10^{5}$ & & & 4 \\
\hline Proliferation of endothelial cells & $1.16 \times 10^{4}$ & Increased & 2.363 & 26 \\
\hline Apoptosis of microvascular endothelial cells & $3.45 \times 10^{4}$ & & 0.261 & 6 \\
\hline Migration of vascular endothelial cells & $4.53 \times 10^{4}$ & & 1.604 & 17 \\
\hline Synthesis of reactive oxygen species & 0.0008 & & -0.132 & 13 \\
\hline Cell spreading of endothelial cells & 0.0014 & Increased & 2.219 & 5 \\
\hline $\begin{array}{l}\text { Endothelial barrier function of vascular } \\
\text { endothelial cells }\end{array}$ & 0.0022 & & & 3 \\
\hline Cell viability of endothelial cells & 0.0026 & & 1.633 & 7 \\
\hline Formation of endothelial tube & 0.0035 & & & 4 \\
\hline Generation of reactive oxygen species & 0.0045 & & 0.714 & 5 \\
\hline Production of reactive oxygen species & 0.0050 & & -0.566 & 10 \\
\hline Morphology of endothelial cells & 0.0068 & & & 3 \\
\hline Cell movement of muscle cells & 0.0068 & & & 4 \\
\hline Cell spreading of vascular endothelial cells & 0.0090 & & & 3 \\
\hline Survival of vascular endothelial cells & 0.0095 & & 1 & 5 \\
\hline $\begin{array}{l}\text { Transendothelial migration of regulatory } \mathrm{T} \\
\text { lymphocytes }\end{array}$ & 0.0097 & & & 2 \\
\hline Cell movement of muscle precursor cells & 0.0097 & & & 2 \\
\hline Occlusion of artery & 0.0138 & & & 5 \\
\hline Tubulation of endothelial cells & 0.0147 & & 0.632 & 10 \\
\hline Angiogenesis of endothelial cells & 0.0147 & & & 3 \\
\hline Differentiation of vascular endothelial cells & 0.0147 & & & 3 \\
\hline Transendothelial migration of T lymphocytes & 0.0147 & & & 3 \\
\hline Coronary artery disease & 0.0157 & & & 2 \\
\hline Adhesion of muscle cells & 0.0157 & & & 2 \\
\hline
\end{tabular}


Table 2. Cont.

\begin{tabular}{|c|c|c|c|c|}
\hline Diseases or Functions Annotation & $p$-Value & Predicted Activation State & Activation z-Score & \# Molecules \\
\hline Sliding of myofilaments & 0.0173 & & & 5 \\
\hline Biosynthesis of hydrogen peroxide & 0.0182 & & & 3 \\
\hline Atherosclerosis & 0.0269 & & & 4 \\
\hline Differentiation of endothelial cells & 0.0285 & & 0.447 & 5 \\
\hline Migration of endothelial progenitor cells & 0.0312 & & & 2 \\
\hline Proliferation of myoblasts & 0.0312 & & & 2 \\
\hline Cell proliferation of vascular endothelial cells & 0.0323 & Increased & 2.735 & 12 \\
\hline Shape change of vascular endothelial cells & 0.0371 & & 0.555 & 5 \\
\hline Permeability of endothelial progenitor cells & 0.0413 & & & 1 \\
\hline Injury of cardiomyocytes & 0.0413 & & & 1 \\
\hline Diastolic heart failure & 0.0413 & & & 1 \\
\hline Perfusion of myocardium & 0.0413 & & & 1 \\
\hline Vasoconstriction of artery & 0.0413 & & & 1 \\
\hline $\begin{array}{l}\text { Arrest in mid-G1 phase of microvascular } \\
\text { endothelial cells }\end{array}$ & 0.0413 & & & 1 \\
\hline Anoikis of vascular endothelial cells & 0.0413 & & & 1 \\
\hline Delay in initiation of fusion of myoblasts & 0.0413 & & & 1 \\
\hline Aggregation of myoblasts & 0.0413 & & & 1 \\
\hline Activation of myoblasts & 0.0413 & & & 1 \\
\hline Activation of myotube & 0.0413 & & & 1 \\
\hline Morphology of cardiovascular system & 0.0423 & & & 6 \\
\hline
\end{tabular}

Table 3. Inflammatory pathways and list of proteins modulated in eEV-IL-3 with respect to eEV. Bold pathways are statistically significant.

Ingenuity Canonical Pathways

Agranulocyte Adhesion and Diapedesis

Leukocyte Extravasation Signaling

NF-kB Activation by Viruses

2.24

Granulocyte Adhesion, and Diapedesis

2.23

IL-8 Signaling

Role of NFAT in Regulation of the Immune Response

4.76

$$
-\log (p \text {-Value })
$$

GA2, ITGA5, ITGA6, ITGAV, ITGB1, ITGB3, MAPK1, RALA, RALB, RAP2B

CD99, CDH5, GLG1, GNAI2, ICAM1, ICAM2, ITGA2, ITGA5, ITGA6, ITGB1, ITGB3, MSN, PECAM1, RDX

ANGPT2, CSTB, GNAI2, GNB1, GNG12, ICAM1, IQGAP1, ITGAV, ITGB3, LASP1, MAP2K1, MAPK1, RALA, RALB, RAP2B, RHOC

CALM1, CHP1, GNA11, GNAI2, GNAQ, GNB1, 1.98 GNG12, HLA-A, HLA-B, MAP2K1, MAPK1, RALA, RALB, RAP2B, XPO1 
Table 3. Cont.

\begin{tabular}{|c|c|c|}
\hline Ingenuity Canonical Pathways & $-\log (p$-Value $)$ & Gene List \\
\hline Acute Phase Response Signaling & 1.92 & $\begin{array}{l}\text { A2M, CP, FGA, FN1, HMOX2, HNRNPK, HP, } \\
\text { MAP2K1, MAPK1, RALA, RALB, RAP2B, } \\
\text { RBP4, SERPINE1 }\end{array}$ \\
\hline Complement System & 1.81 & C1QBP, C6, C8B, CD59, MASP1 \\
\hline IL-1 Signaling & 1.46 & $\begin{array}{l}\text { GNA11, GNAI2, GNAQ, GNB1, GNG12, MAPK1, } \\
\text { PRKAR1A, PRKAR2A }\end{array}$ \\
\hline CCR3 Signaling in Eosinophils & 1.31 & $\begin{array}{l}\text { CALM1, CFL1, GNAI2, GNB1, GNG12, MAP2K1, } \\
\text { MAPK1, RALA, RALB, RAP2B }\end{array}$ \\
\hline $\begin{array}{l}\text { Regulation of IL-2 Expression in Activated and Anergic } \\
\text { T Lymphocytes }\end{array}$ & 1.21 & $\begin{array}{l}\text { CALM1, CHP1, MAP2K1, MAPK1, RALA, } \\
\text { RALB, RAP2B }\end{array}$ \\
\hline Role of NFAT in Cardiac Hypertrophy & 1.18 & $\begin{array}{l}\text { CALM1, CHP1, GNAI2, GNAQ, GNB1, GNG12, } \\
\text { MAP2K1, MAPK1, PDIA3, PRKAR1A, PRKAR2A, } \\
\text { RALA, RALB, RAP2B }\end{array}$ \\
\hline IL-12 Signaling and Production in Macrophages & 0.93 & $\begin{array}{l}\text { APOB, APOC2, CLU, MAP2K1, MAPK1, MST1, } \\
\text { PCYOX1, PON1, RBP4 }\end{array}$ \\
\hline IL-3 Signaling & 0.78 & CHP1, MAP2K1, MAPK1, RALA, RALB, RAP2B \\
\hline OX40 Signaling Pathway & 0.76 & B2M, HLA-A, HLA-B, TNFSF4 \\
\hline IL-2 Signaling & 0.75 & MAP2K1, MAPK1, RALA, RALB, RAP2B \\
\hline IL-4 Signaling & 0.73 & HLA-A, HLA-B, HMGA1, RALA, RALB, RAP2B \\
\hline GM-CSF Signaling & 0.61 & MAP2K1, MAPK1, RALA, RALB, RAP2B \\
\hline IL-15 Signaling & 0.58 & MAP2K1, MAPK1, RALA, RALB, RAP2B \\
\hline IL-17 Signaling & 0.47 & MAP2K1, MAPK1, RALA, RALB, RAP2B \\
\hline IL-6 Signaling & 0.31 & A2M, MAP2K1, MAPK1, RALA, RALB, RAP2B \\
\hline NF-kB Signaling & 0 & RALA, RALB, RAP2B, UBE2N, UBE2V1 \\
\hline CD40 Signaling & 0 & ICAM1, MAP2K1, MAPK1 \\
\hline
\end{tabular}

To evaluate whether eEV cargo may specifically reflect the micro environmental cues driving their release, eEV-IL-3 protein cargo was also compared to EV released by HUVEC in response to TNF- $\alpha$ (eEV-TNF- $\alpha$ ) [43]. As shown in Table S4, only a few proteins are shared by eEV-IL-3 and eEV-TNF- $\alpha$.

\subsection{MEK1/2/eNOS/GC Pathway Is Involved in eEV-Mediated Cardio-Protection}

Since MEK1/2 was enriched while caveolin 1 reduced in eEV, and only eEV were found effective in inducing cardioprotection ex vivo, the MEK1/2/eNOS/GC pathways were investigated both in vitro and in the whole heart. To mimic the ex vivo experiments, transwells experiments were first performed using different MEK1/2/eNOS/GC inhibitors. As reported in Figure 5a, pretreatment with the MEK1/2 (U0126), eNOS (L-NNA), and GC (ODQ) inhibitors prevented eEV-mediated protection. Ex vivo experiments were also performed to corroborate these results. As shown in Figure $5 \mathrm{~b}$ all inhibitors were effective in impairing eEV-mediated ex-vivo cardioprotection $(61 \pm 1 \%, 65 \pm 1 \%$, and $63 \pm 3 \%$ respectively). None of the inhibitors had effects when used alone neither in vitro nor ex vivo (Figure S1). 
a)

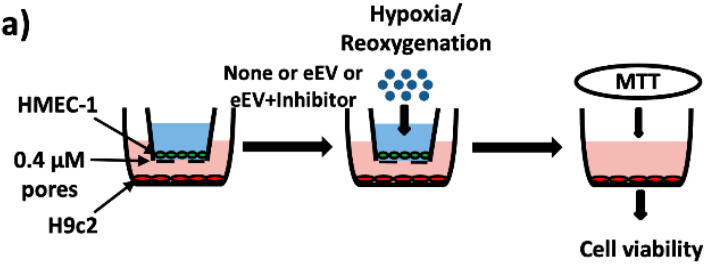

c)

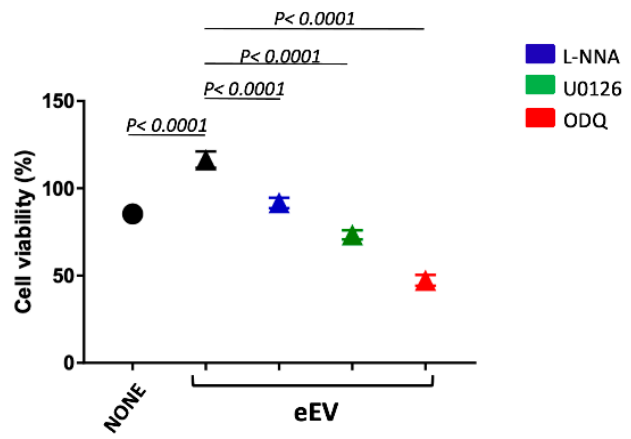

b)

\begin{tabular}{|c|c|c|c|}
\hline Stabilization & 造 EV & Ischemia & Reperfusion \\
\hline \multicolumn{4}{|c|}{ eEV + Inhibitor (Group 8-9-10) } \\
\hline Stabilization & $\begin{array}{c}\mathrm{EV}+ \\
\text { Inhibitor }\end{array}$ & Ischemia & Reperfusion \\
\hline $30 \mathrm{~min}$ & $5+10 \min$ & $30 \mathrm{~min}$ & $60 \mathrm{~min}$ \\
\hline
\end{tabular}

d)

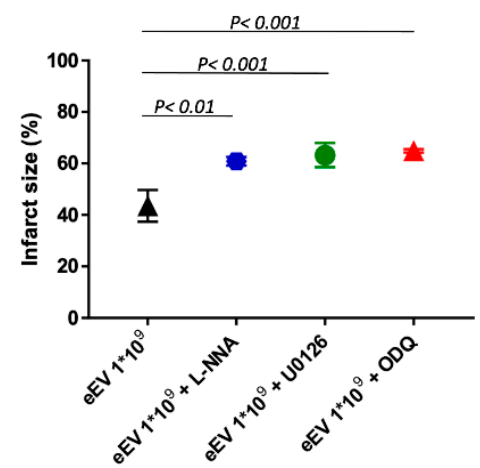

Figure 5. Mitogen-Activated Protein Kinase Kinase (MEK1/2)/endothelial-nitric oxide-synthase (eNOS)/ guanylyl-cyclase (GC) inhibitors prevented cardio-protection in in-vitro and ex-vivo models. (a) Representative image of transwell assay of HMEC-1 cells seeded in the upper and H9c2 cells in the lower well. HMEC-1 cells treated or not with eEV or eEV-IL-3 were subjected to H/R condition. MTT assay was performed on H9c2 cells. (b) Timeline of ex vivo protocol. Protocols of ischemia (black boxes) and reperfusion (white boxes) in isolated rat hearts. After stabilization (white boxes), Krebs-Henseleit buffer solution (KHS) was infused with eEV and/or inhibitors (gray boxes) via a collateral line. eEV $\left(1 \times 10^{9}\right)$ for $10 \mathrm{~min}$ before ischemia, while inhibitors were given $5 \mathrm{~min}$ (total time infusion was $15 \mathrm{~min}$ ) as indicated. (c) Cell viability of H9c2 cells subjected to eEV treatment with different inhibitors in H/R conditions. MEK1/2/eNOS/GC inhibitors abolished eEV-protective effect. $p<0.0001$ NONE vs. eEV; $p<0.0001$ MEK1/2/eNOS/GC inhibitors vs. eEV. Data were normalized to the mean value of normoxic control (CTRL N). (d) Infarct size in isolated rat hearts exposed to eEV and pretreated with different inhibitors. The protective effect of eEV $\left(1 \times 10^{9}\right)$ was abrogated by pretreatment with the antagonist of MEK1/2, U0126 $(n=3)$, the inhibitor of eNOS, L-NNA $(n=3)$, and the blocker of GC, ODQ $(n=3) . p<0.01 \mathrm{eEV}$ vs. eNOS inhibitor; $p<0.0001 \mathrm{eEV}$ vs. MEK1/2 and GC inhibitors.

3.6. eEV But Not eEV-IL-3 Treatment Induces the Expression Bcl-2 and the Phosphorylation of eNOS In Vitro

To validate the above results, the expression of MEK1/2 and the phosphorylation of eNOS were evaluated in vitro. The results reported in Figure 6A clearly demonstrate that $\mathrm{eEV}$, unlike eEV-IL-3, are able to induce the expression of MEK1/2 and the phosphorylation of eNOS in H9c2 cells in co-cultures. The phosphorylation of eNOS was also detected upon a direct stimulation of $\mathrm{H} 9 \mathrm{c} 2$ cells with $\mathrm{eEV}$. On the contrary, MEK1/2 expression was not significantly increased upon eEV treatment (Figure 6B). The high basal MEK1/2 expression in $\mathrm{H} 9 \mathrm{c} 2$ cells directly subjected to $\mathrm{H} / \mathrm{R}$ may possibly explain these results.

Since bioinformatics analysis indicated that eEV-IL-3 are enriched in proteins involved in the IL-3 signaling pathways, and among them, a number of these proteins linked to the apoptosis signaling were found (Table 1), the expression of the anti-apoptotic protein Bcl-2 was also evaluated both in co-culture and upon direct stimulation. As shown in Figure $6 \mathrm{~A}, \mathrm{~B}, \mathrm{eEV}$, unlike eEV-IL-3, significantly increased the expression of Bcl-2. These results confirm the ability of eEV to trigger anti-apoptotic cues and straighten the proapoptotic action of eEV-IL-3 in H/R setting. 
A)

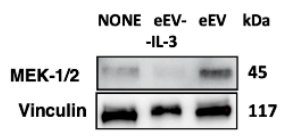

B)

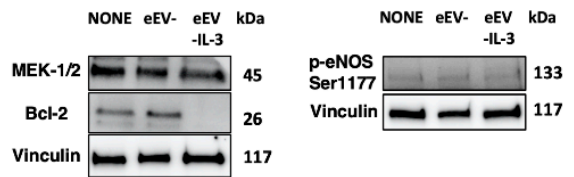

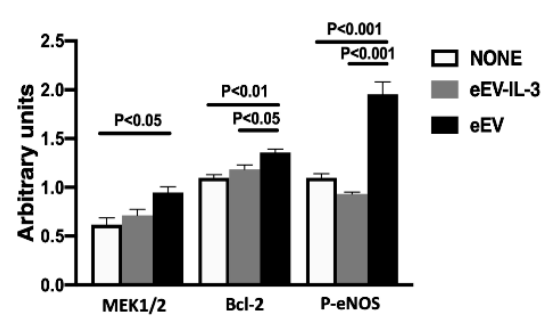

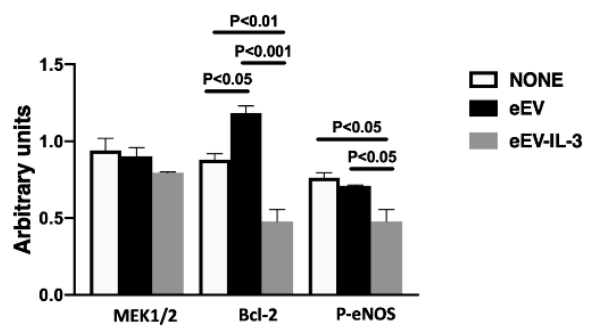

Figure 6. Effects of eEV and eEV-IL-3 on cardioprotective pathway. (A) Westen blot analysis of eEV and eEV-IL-3 in vitro treatment (transwell experiments). The expression of MEK1/2, p-eNOS, and B-cell-lymphoma-2 (Bcl-2) was evaluated in $\mathrm{H} 9 \mathrm{c} 2$ cells exposed to $\mathrm{H} / \mathrm{R}$ conditions and eEV or eEV-IL-3 treatment, normalized to vinculin. Untreated cells served as internal control (NONE) $(n=3)$. MEK1 $/ 2: p<0.05$ NONE vs. eEV $(n=4)$; Bcl-2: $p<0.05$ eEV vs. eEV-IL-3; $p<0.01$ NONE vs. eEV $(n=3)$; p-eNOS: $p<0.01$ NONE vs. eEV and eEV vs. eEV-IL-3 $(n=3)$. (B) Western blot analysis of eEV and eEV-IL-3 in vitro treatment. The expression of MEK1/2, p-eNOS, and Bcl-2 was evaluated in H9c2 cells directly exposed to $H / R$ conditions and eEV or eEV-IL-3 treatment, normalized to vinculin. Untreated cells served as internal control (NONE). Bcl-2: $p<0.001$ eEV vs. eEV-IL-3; $p<0.05$ NONE vs. eEV; $p<0.01$ NONE vs. eEV-IL-3; p-eNOS: $p<0.05$ eEV vs. eEV-IL-3; $p<0.05$ NONE vs. eEV-IL-3 $(n=3)$.

\section{Discussion}

In the present study and consistent with our hypothesis, we demonstrated that the inflammatory microenvironment, recapitulated by eEV-IL-3, prevents cardioprotection. Of note, cardioprotective effects against I/R damage were detected upon eEV treatment. Moreover, we noticed that both the integrity of the endothelial layer and functional MEK1/2/eNOS/GC pathways are crucial for eEV-mediated cardioprotection.

$\mathrm{EV}$ can be released by different cell types and contribute to cell-to-cell communication either at local or distant site both in physiological and pathological settings $[15,16,44]$. In the heart, the ischemic damage induces the release of EV from cells of different origin [19,45]. Actually, it has been extensively reported that cells in the ischemic microenvironment release $\mathrm{EV}$, which differ in term of composition and impact on target cells [45]. The biological relevance of eEV in the activation of signals leading to cardiovascular damage and/or tissue regeneration has been extensively documented [19]. Hypoxia associated to the ischemic injury primarily drives changes in $\mathrm{EC}$ and in their released $\mathrm{eEV}$, particularly in their non-genetic and genetic cargo [22,23]. However, shift in the eEV molecular content in vivo can also result from the inflammatory response elicited by resident and recruited inflammatory cells [46]. In turn, this may drive the activation of damaging cues as well as long-lasting regenerative programs in the ischemic tissue [46]. Since the effects of EV released from EC in response to the inflammatory stimuli have been poorly investigated, we aimed to evaluate whether and how EV released by EC exposed to the inflammatory cytokine IL-3 impact on cardioprotection. Originally, IL-3 was described as a hematopoietic cytokine acting on progenitors and mature cells [11]. However, it has been also shown that IL-3 can functionally activate EC and can induce angiogenesis [14]. Apart from the direct effects on EC, recent evidence demonstrated that IL-3 can also act as paracrine mediator via EV [15]. Davidson et al. [47] have shown that eEV released from normoxic EC protect cardiomyocytes from H/R. Consistently, we noticed that eEV, unlike eEV-IL-3, protect H9c2 cells against $\mathrm{H} / \mathrm{R}$ injury. Moreover, to mirror the physiological setting in which a close interaction and cross-talk between EC and cardiomyocytes dictate the response to injury, 
transwell experiments were also performed. We demonstrated that, although less effective than $\mathrm{eEV}$, eEV-IL-3 preconditioning reduced the percentage of cardiac cell death, suggesting that, even in response to the inflammatory stimulus, EC, in vitro stimulated, release EV enriched in a cardioprotective machinery. As a matter of fact, proteomic analysis comparing eEV and eEV-IL-3 demonstrated that both eEV and eEV-IL-3 are equipped with proteins retaining cardioprotective properties. More importantly, we showed that most of these proteins were enriched in eEV-IL-3. Pretreatment of EC with an anti-IL-3R antibody before IL-3 stimulation provide evidence that the enriched proteins strictly depended on IL-3 challenge. Surprisingly, but in line with the results obtained when $\mathrm{H} 9 \mathrm{c} 2$ cells were directly stimulated with $\mathrm{EV}$, in the ex vivo experiments, only eEV protected the myocardium from I/R injury.

During I/R injury, the loss of EC physiological functions impacts on tissue outcome [7,8]. Our finding that pretreatment of EC with Triton prevented eEV-mediated protection supports the notion that a preserved endothelium is required for eEV effectiveness. miRNA EV cargo has been reported to induce cardioprotection in several models [18]. However, while eEV-IL-3 were found enriched in proangiogenic miRNAs [15], no protective effects were detected ex vivo. The short ex vivo exposure to eEV-IL-3 during the I/R protocol may explain their failure to activate the angiogenic switch via miRNA transfer. Nevertheless, to gain insight on eEV and eEV-IL-3 discrete biological actions, the entire EV cargo was deeply analyzed. In particular, we found that eEV-IL-3, besides being enriched in proteins associated with the oxidative stress related pathways, ER stress, Calcium signaling, VEGF, and the Nitric Oxide Signaling pathway, is also enriched in the main coat protein of caveolae, caveolin 1 . It has been extensively reported that caveolin 1 impacts on oxidative stress and cardiac disease by controlling eNOS activity [48]. eNOS is mainly expressed by EC and heart myocytes [49]. After association with caveolae, eNOS interacts with caveolin 1 in EC and caveolin 3 in cardiac myocytes [50] and becomes inactive. Consistently, it has been reported that in the diabetes setting, the eNOS-derived NO release can be improved by inhibiting the binding of eNOS to caveolin 1 [51]. Similarly, the reduced cardioprotective effect of ischemic preconditioning in diabetic rats has been linked to the up-regulation of caveolin 1 [52]. These observations sustain the possibility that the lack of effectiveness of eEV-IL-3, rather than in the transfer of the entire cardioprotective machinery, may rely on a more efficient caveolin 1 binding to eNOS, holding eNOS in an inactive conformation. This hypothesis has been validated by our in vitro experiments showing that eEV, unlike eEV-IL-3, triggers eNOS phosphorylation. Alternatively, since eEV-IL-3 were also found enriched in inflammation-related proteins, their transfer into resident cardiac macrophages or fibroblasts in the ischemic myocardium may induce a rapid stimulation of the inflammatory response $[25,26,53,54]$, which translates into the local activation of death signals preventing protection. A detrimental role of $\mathrm{NFKB}$ in preconditioning-induced protection against I/ $R$ has been also reported $[55,56]$. We found that along with proteins associated with the Acute Phase Response Signaling, the IL-1 and IL-8 pathways, a number of proteins related to nuclear NFKB were found enriched in eEV-IL-3. We also noticed that eEV-IL-3 were equipped with many proteins generally associated with the IL-3 pro-inflammatory signaling pathway, thus suggesting that the pro-inflammatory properties of IL-3 can be transferred to eEV-IL-3. Finally, data obtained by comparing eEV-IL-3 and eEV-TNF- $\alpha$ protein content [43] further sustain the notion that the local microenvironment dictates the unique eEV cargo.

Several endogenous protective mechanisms are known to be activated in the heart upon I/R, even via EV [55]. Essentially, different molecules including eNOS, PI3-kinase/Akt, ERK1/2, protein kinase C, STAT, and many others were found involved in preconditioning protective signaling $[27,28]$. In the present study, we found MEK1/2, HSP90, and caveolin 1 among proteins differentially expressed in eEV and eEV-IL-3, and that the activation of MEK1/2/eNOS/GC pathways by eEV is relevant for their cardioprotective action. Moreover, since the HSP90 acts to protect cells against stress-induced injury [57], its enrichment in eEV may trigger anti-apoptotic signals. Consistent with this possibility, $\mathrm{Bcl}-2$ expression 
was increased in cells treated with eEV. Therefore, our data suggest that the selective activation of specific signaling components may elicit eEV-mediated cardioprotection (Figure 7). However, since the EV mechanism of action strictly relies on their entire molecular cargo, additional molecules carried by eEV and eEV-IL-3 may dictate their discrete biological actions.

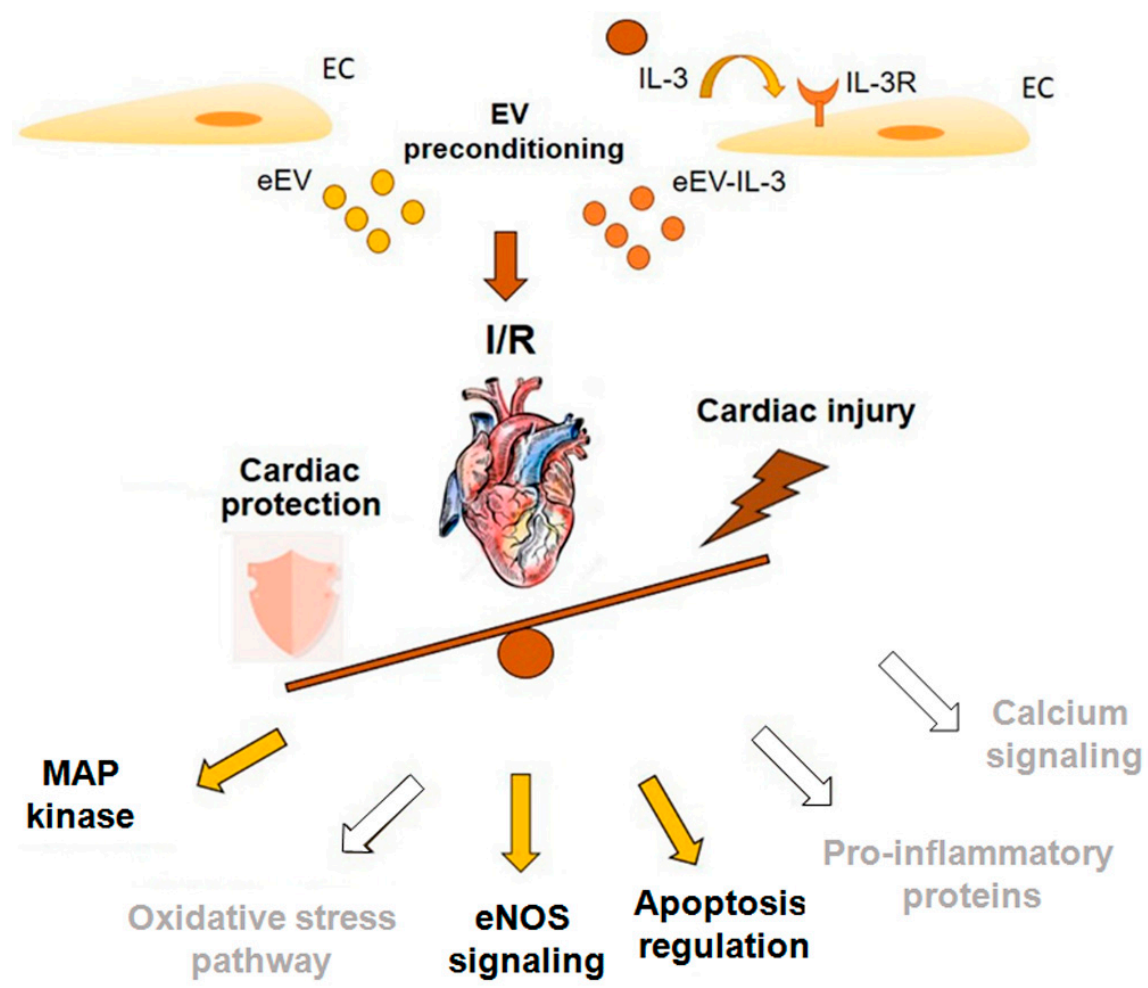

Figure 7. Schematic representation of eEV and eEV-IL-3 action on I/R injury. eEV and eEV-IL-3 were administered ex-vivo prior to I/R injury. A selective activation of specific signaling components likely mediates eEV cardioprotection. Different molecules can drive preconditioning protective signaling upon eEV treatment. eNOS, ERK1/2, and the anti-apoptotic protein Bcl-2 were validated. Other predicted but not validated pathways include PI3-kinase/Akt and oxidative stress (indicated by the gray font-white arrows). In response to eEV-IL-3, the transfer of inflammatory, apoptosis mediators and caveolin 1 likely change the balance and may trigger death signaling ex vivo.

Overall, this study demonstrated that IL-3 released in an inflammatory setting drives changes in eEV-IL-3 protein cargo that may contribute to the lack of cardioprotection (Figure 7). Different hypotheses can be postulated to explain the failure of eEV-IL-3 to induce protection: (a) the transfer of caveolin 1, which harms eNOS activity; (b) the transfer of inflammatory mediators activating death signaling in cardiomyoblasts, and (c) the activation of resident macrophages / fibroblasts boosting the inflammatory cascade [25]. The relevance of the inflammatory response associated with eEV-IL-3 challenge is supported by the bioinformatics analysis and by the observation that IL-3, itself, induced a powerful damaging effect. Nevertheless, our data shed light on eEV and eEV-IL-3 protein cargo and provide evidence for the ability of eEV to convey cardioprotective factors in the whole heart. Finally, our data suggest that the enrichment of MEK1/2 and HSP90 as well as the reduced expression of caveolin 1 in eEV may account for their mechanism of action.

Supplementary Materials: The following are available online at https:/ /www.mdpi.com/2073-440 9/10/1/13/s1, Figure S1: Table S1: Proteins commonly expressed by eEV and eEV-IL-3, Table S2: Mass spectrometry data of IL-8 pathway comparing eEV and eEV-IL-3, Table S3: Mass spectrometry data of NF-kB pathway comparing eEV and eEV-IL-3. Table S4: Mass spectrometry data of inflammatory related proteins identified in eEV and eEV-IL-3 compared with proteins identified in EV released by HUVEC in response to TNF- $\alpha$ (EV-TNF- $\alpha)$. 
Author Contributions: C.P. performed the study conception and designed the experiments. S.F. performed in vitro and ex vivo experiments and prepared Figures 1-4 panel D, Figures 5 and 6. M.T. performed protein pathway analysis and prepared Figure 4 panel A-C, and Figure 7. T.L. performed Western blot analyses. K.E.F. performed label-free mass spectrometry analysis. F.R. performed EV isolation from EC. S.C. contribute to perform ex vivo experiments and data analysis. G.A. contributed to the study conception and data interpretation. I.G. and V.D. performed TEM. G.C. contributed to data interpretation. P.P. revised the manuscript critically for important intellectual content. M.F.B. performed the study conception and design, and wrote the manuscript with input from all authors. All authors revised the manuscript. All authors have read and agreed to the published version of the manuscript.

Funding: This work was supported by grant No. 071215 from 2i3T to G.C. and M.F.B., Fondi di Beneficenza Intesa San Paolo No. 375-2019 to CP and MFB, and EU-COST BM1203 to K.E.F. and M.F.B.

Institutional Review Board Statement: The study was conducted according to the guidelines of the Declaration of Helsinki, and approved by the Institutional Review Board (or Ethics Committee) of Italian National Institute of Health Guide for the care and use of laboratory Animals (protocol code E669C.N.OVL approval date 19/5/2018).

Informed Consent Statement: “Not applicable" for studies not involving humans.

Acknowledgments: We thank Ann-Kristin Frøyset for performing interpretation of MS data.

Author Contributions: G.C. is a component of Scientific Advisory Board of Unicyte AG. The other authors have no conflicts of interest to declare.

Conflicts of Interest: The authors declare no conflict of interest.

$\begin{array}{ll}\text { Abbreviations } \\ \text { ACN } & \text { Acetonitrile } \\ \text { Bcl-2 } & \text { B-cell-lymphoma-2 } \\ \text { CVDs } & \text { Cardiovascular Diseases } \\ \text { DMSO } & \text { Dimethyl Sulfoxide } \\ \text { EC } & \text { Endothelial Cell } \\ \text { eEV } & \text { EV released by EC } \\ \text { eEV-IL-3 } & \text { EV released by EC treated with IL-3 } \\ \text { eNOS } & \text { Endothelial Nitric Oxide Synthase } \\ \text { EV } & \text { Extracellular Vesicles } \\ \text { FACS } & \text { Fluorescence-Activated Cell Sorting } \\ \text { FBS } & \text { Fetal Bovine Serum } \\ \text { FDR } & \text { False Discovery Rate } \\ \text { GC } & \text { Guanylyl Cyclase } \\ \text { GO } & \text { Gene Ontology } \\ \text { H9c2 } & \text { Rat Embryonic Cardiac Myoblast } \\ \text { HMEC-1 } & \text { Human Endothelial Cell-1 } \\ \text { HUVEC } & \text { Human Umbilical Vein Endothelial Cell } \\ \text { I/R } & \text { Ischemia/Reperfusion } \\ \text { IL-3 } & \text { Interleukin-3 } \\ \text { IPA } & \text { Ingenuity Pathway Analysis } \\ \text { KHS } & \text { Krebs-Henseleit Buffer Solution } \\ \text { L-NNA } & \text { N Omega-Nitro-L-Arginine } \\ \text { MEK1/2 } & \text { Mitogen-Activated Protein Kinase 1/2 } \\ \text { MI } & \text { Myocardial Infarction } \\ \text { NO } & \text { Nitric Oxide } \\ \text { NTA } & \text { Nanoparticle Tracking Analysis } \\ \text { ODQ } & \text { Oxadiazolo[4,3-a]quinoxalin-1-one } \\ \text { PPCI } & \text { Primary Percutaneous Coronary Intervention } \\ \text { RNS } & \text { Reactive Nitrogen Species } \\ \text { ROS } & \text { Reactive Oxygen Species } \\ \text { TEM } & \text { Transmission Electron Microscopy } \\ \text { TFA } & \text { Trifluoroacetic Acid } \\ & \end{array}$




\section{References}

1. Shi, A.; Tao, Z.; Wei, P.; Zhao, J. Epidemiological aspects of heart diseases. Exp. Ther. Med. 2016, 12, 1645-1650. [CrossRef] [PubMed]

2. Smith, E.J.; Mathur, A.; Rothman, M.T. Recent advances in primary percutaneous intervention for acute myocardial infarction. Heart 2005, 91, 1533-1536. [CrossRef] [PubMed]

3. Sezer, M.; Van Royen, N.; Umman, B.; Bugra, Z.; Bulluck, H.; Hausenloy, D.J.; Umman, S. Coronary Microvascular Injury in Reperfused Acute Myocardial Infarction: A View from an Integrative Perspective. J. Am. Hear. Assoc. 2018, 7, 009949. [CrossRef] [PubMed]

4. Hausenloy, D.J. Conditioning the heart to prevent myocardial reperfusion injury during PPCI. Eur. Hear. J. Acute Cardiovasc. Care 2012, 1, 13-32. [CrossRef]

5. Penna, C.; Granata, R.; Tocchetti, C.G.; Gallo, M.P.; Alloatti, G.; Pagliaro, P. Endogenous Cardioprotective Agents: Role in Pre and Postconditioning. Curr. Drug Targets 2015, 16, 843-867. [CrossRef]

6. Bulluck, H.; Yellon, D.M.; Hausenloy, D.J. Reducing myocardial infarct size: Challenges and future opportunities. Heart 2015, 102, 341-348. [CrossRef]

7. Yellon, D.M.; Hausenloy, D.J. Myocardial Reperfusion Injury. N. Engl. J. Med. 2007, 357, 1121-1135. [CrossRef]

8. Zhao, Z.-Q. Oxidative stress-elicited myocardial apoptosis during reperfusion. Curr. Opin. Pharmacol. 2004, 4, 159-165. [CrossRef]

9. Frangogiannis, N.G. The inflammatory response in myocardial injury, repair, and remodelling. Nat. Rev. Cardiol. 2014, 11, 255-265. [CrossRef]

10. Bartekova, M.; Radosinska, J.; Jelemensky, M.; Dhalla, N.S. Role of cytokines and inflammation in heart function during health and disease. Heart Fail. Rev. 2018, 23, 733-758. [CrossRef]

11. Greenberger, J.S.; Eckner, R.J.; Sakakeeny, M.; Marks, P.; Reid, D.; Nabel, G.; Hapel, A.; Ihle, J.N.; Humphries, K.C. Interleukin 3-dependent hematopoietic progenitor cell lines. Fed. Proc. 1983, 42, 2762-2771. [PubMed]

12. Brizzi, M.F.; Garbarino, G.; Rossi, P.R.; Pagliardi, G.L.; Arduino, C.; Avanzi, G.C.; Pegoraro, L. Interleukin 3 stimulates proliferation and triggers endothelial-leukocyte adhesion molecule 1 gene activation of human endothelial cells. J. Clin. Investig. 1993, 91, 2887-2892. [CrossRef] [PubMed]

13. Ihle, J.N. Interleukin-3 and Hematopoiesis. Chem. Immunol. Allergy 1992, 51, 65-106. [CrossRef]

14. Dentelli, P.; Del Sorbo, L.; Rosso, A.; Molinar, A.; Garbarino, G.; Camussi, G.; Pegoraro, L.; Brizzi, M.F. Human IL-3 stimulates endothelial cell motility and promotes in vivo new vessel formation. J. Immunol. 1999, 163, 2151-2159.

15. Lombardo, G.; Dentelli, P.; Togliatto, G.; Rosso, A.; Gili, M.; Gallo, S.; Deregibus, M.C.; Camussi, G.; Brizzi, M.F. Activated Stat5 trafficking Via Endothelial Cell-derived Extracellular Vesicles Controls IL-3 Pro-angiogenic Paracrine Action. Sci. Rep. 2016, 6, 25689. [CrossRef]

16. Todorova, D.; Simoncini, S.; Lacroix, R.; Sabatier, F.; Dignat-George, F. Extracellular Vesicles in Angiogenesis. Circ. Res. 2017, 120, 1658-1673. [CrossRef] [PubMed]

17. Oggero, S.; Austin-Williams, S.; Norling, L.V. The Contrasting Role of Extracellular Vesicles in Vascular Inflammation and Tissue Repair. Front. Pharmacol. 2019, 10, 1479. [CrossRef] [PubMed]

18. Brill, A.; Dashevsky, O.; Rivo, J.; Gozal, Y.; Varon, D. Platelet-derived microparticles induce angiogenesis and stimulate postischemic revascularization. Cardiovasc. Res. 2005, 67, 30-38. [CrossRef]

19. Caccioppo, A.; Franchin, L.; Grosso, A.; Angelini, F.; D’Ascenzo, F.; Brizzi, M.F. Ischemia Reperfusion Injury: Mechanisms of Damage/Protection and Novel Strategies for Cardiac Recovery/Regeneration. Int. J. Mol. Sci. 2019, 20, 5024. [CrossRef] [PubMed]

20. Giricz, Z.; Varga, Z.V.; Baranyai, T.; Bencsik, P.; Pálóczi, K.; Kittel, Á.; Buzás, E.I.; Ferdinandy, P. Cardioprotection by remote ischemic preconditioning of the rat heart is mediated by extracellular vesicles. J. Mol. Cell. Cardiol. 2014, 68, 75-78. [CrossRef]

21. Liu, M.; Wang, Y.; Zhu, Q.; Zhao, J.; Wang, Y.; Shang, M.; Liu, M.; Wu, Y.; Song, J.; Liu, Y. Protective effects of circulating microvesicles derived from ischemic preconditioning on myocardial ischemia/reperfusion injury in rats by inhibiting endoplasmic reticulum stress. Apoptosis 2018, 23, 436-448. [CrossRef] [PubMed]

22. Zhang, Q.; Shang, M.; Zhang, M.; Wang, Y.; Chen, Y.; Wu, Y.; Liu, M.-L.; Song, J.; Liu, Y. Microvesicles derived from hypoxia/reoxygenation-treated human umbilical vein endothelial cells promote apoptosis and oxidative stress in H9c2 cardiomyocytes. BMC Cell Biol. 2016, 17, 25. [CrossRef]

23. Loyer, X.; Zlatanova, I.; Devue, C.; Yin, M.; Howangyin, K.Y.; Klaihmon, P.; Guerin, C.L.; Kheloufi, M.; Vilar, J.; Zannis, K.; et al. Intra-Cardiac Release of Extracellular Vesicles Shapes Inflammation Following Myocardial Infarction. Circ. Res. 2018, 123, 100-106. [CrossRef] [PubMed]

24. Frantz, S.; Nahrendorf, M. Cardiac macrophages and their role in ischaemic heart disease. Cardiovasc. Res. 2014, 102, 240-248. [CrossRef] [PubMed]

25. Kawaguchi, M.; Takahashi, M.; Hata, T.; Kashima, Y.; Usui, F.; Morimoto, H.; Izawa, A.; Takahashi, Y.; Masumoto, J.; Koyama, J.; et al. Inflammasome Activation of Cardiac Fibroblasts Is Essential for Myocardial Ischemia/Reperfusion Injury. Circulation 2011, 123, 594-604. [CrossRef] [PubMed]

26. Sandanger, Ø.; Ranheim, T.; Vinge, L.E.; Bliksøen, M.; Alfsnes, K.; Finsen, A.V.; Dahl, C.P.; Askevold, E.T.; Florholmen, G.; Christensen, G.; et al. The NLRP3 inflammasome is up-regulated in cardiac fibroblasts and mediates myocardial ischaemiareperfusion injury. Cardiovasc. Res. 2013, 99, 164-174. [CrossRef] [PubMed] 
27. Penna, C.; Cappello, S.; Mancardi, D.; Raimondo, S.; Rastaldo, R.; Gattullo, D.; Losano, G.; Pagliaro, P. Post-conditioning reduces infarct size in the isolated rat heart: Role of coronary flow and pressure and the nitric oxide/cGMP pathway. Basic Res. Cardiol. 2005, 101, 168-179. [CrossRef]

28. Gough, D.J.; Koetz, L.; Levy, D.E. The MEK-ERK pathway is necessary for serine phosphorylation of mitochondrial STAT3 and Ras-mediated transformation. PLoS ONE 2013, 8, e83395. [CrossRef]

29. Femminò, S.; Penna, C.; Bessone, F.; Caldera, F.; Dhakar, N.K.; Cau, D.; Pagliaro, P.; Cavalli, R.; Trotta, F. $\alpha$-Cyclodextrin and $\alpha$-Cyclodextrin Polymers as Oxygen Nanocarriers to Limit Hypoxia/Reoxygenation Injury: Implications from an In Vitro Model. Polymers 2018, 10, 211. [CrossRef]

30. Wiklander, O.P.B.; Bostancioglu, R.B.; Welsh, J.A.; Zickler, A.M.; Murke, F.; Corso, G.; Felldin, U.; Hagey, D.W.; Evertsson, B.; Liang, X.M.; et al. Systematic Methodological Evaluation of a Multiplex Bead-Based Flow Cytometry Assay for Detection of Extracellular Vesicle Surface Signatures. Front. Immunol. 2018, 9, 1326. [CrossRef]

31. Giusti, I.; Di Francesco, M.; Cantone, L.; D’Ascenzo, S.; Bollati, V.; Carta, G.; Dolo, V. Time-dependent release of extracellular vesicle subpopulations in tumor CABA I cells. Oncol. Rep. 2015, 34, 2752-2759. [CrossRef] [PubMed]

32. Wang, G.; Bi, Y.; Liu, X.; Wei, M.; Zhang, Q. Upregulation of connexin43 by glucose deprivation in H9c2 cells via the extracellular signal-regulated kinase/mitogen-activated protein kinase signaling pathway. Mol. Med. Rep. 2017, 17, 729-734. [CrossRef]

33. Monastyrskaya, E.A.; Andreeva, L.V.; Duchen, M.R.; Wiegant, F.; Bayda, L.A.; Manukhina, E.B.; Malyshev, I.Y. Adaptation to Heat of Cardiomyoblasts in Culture Protects Them against Heat Shock: Role of Nitric Oxide and Heat Shock Proteins. Biochemistry 2003, 68, 816-821. [CrossRef] [PubMed]

34. Bassino, E.; Fornero, S.; Gallo, M.P.; Gallina, C.; Femminò, S.; Levi, R.; Tota, B.; Alloatti, G. Catestatin Exerts Direct Protective Effects on Rat Cardiomyocytes Undergoing Ischemia/Reperfusion by Stimulating PI3K-Akt-GSK3 $\beta$ Pathway and Preserving Mitochondrial Membrane Potential. PLoS ONE 2015, 10, e0119790. [CrossRef] [PubMed]

35. Frøyset, A.K.; Edson, A.; Gharbi, N.; Khan, E.A.; Dondorp, D.; Bai, Q.; Tiraboschi, E.; Suster, M.L.; Connolly, J.B.; Burton, E.A.; et al. Astroglial DJ-1 over-expression up-regulates proteins involved in redox regulation and is neuroprotective in vivo. Redox Biol. 2018, 16, 237-247. [CrossRef] [PubMed]

36. Pathan, M.; Keerthikumar, S.; Chisanga, D.; Alessandro, R.; Ang, C.-S.; Askenase, P.; Batagov, A.O.; Benito-Martin, A.; Camussi, G.; Clayton, A.; et al. A novel community driven software for functional enrichment analysis of extracellular vesicles data. J. Extracell. Vesicles 2017, 6, 1321455. [CrossRef]

37. Penna, C.; Tullio, F.; Femminò, S.; Rocca, C.; Angelone, T.; Cerra, M.C.; Gallo, M.P.; Gesmundo, I.; Fanciulli, A.; Brizzi, M.F.; et al. Obestatin regulates cardiovascular function and promotes cardio-protection through the nitric oxide pathway. J. Cell. Mol. Med. 2017, 21, 3670-3678. [CrossRef]

38. Russo, I.; Femminò, S.; Barale, C.; Tullio, F.; Geuna, S.; Cavalot, F.; Pagliaro, P.; Penna, C. Cardio-protective Properties of Human Platelets Are Lost in Uncontrolled Diabetes Mellitus: A Study in Isolated Rat Hearts. Front. Physiol. 2018, 9, 875. [CrossRef]

39. Raffaella, R.; Paolocci, N.; Chiribiri, A.; Penna, C.; Gattullo, D.; Pagliaro, P. Cytochrome P-450 metabolite of arachidonic acid mediates bradykinin-induced negative inotropic effect. Am. J. Physiol. Circ. Physiol. 2001, 280, H2823-H2832. [CrossRef]

40. Pagliaro, P.; Penna, C.; Raffaella, R.; Mancardi, D.; Crisafulli, A.; Losano, G.; Gattullo, D. Endothelial cytochrome P450 contributes to the acetylcholine-induced cardiodepression in isolated rat hearts. Acta Physiol. Scand. 2004, 182, 11-20. [CrossRef]

41. Rastaldo, R.; Cappello, S.; Folino, A.; Berta, G.N.; Sprio, A.E.; Losano, G.; Samaja, M.; Pagliaro, P. Apelin-13 limits infarct size and improves cardiac postischemic mechanical recovery only if given after ischemia. Am. J. Physiol. Circ. Physiol. 2011, 300, H2308-H2315. [CrossRef] [PubMed]

42. Bøtker, H.E.; Hausenloy, D.; Andreadou, I.; Antonucci, S.; Boengler, K.; Davidson, S.M.; Deshwal, S.; Devaux, Y.; Di Lisa, F.; Di Sante, M.; et al. Practical guidelines for rigor and reproducibility in preclinical and clinical studies on cardioprotection. Basic Res. Cardiol. 2018, 113, 1-73. [CrossRef] [PubMed]

43. Li, B.-W.; Li, L.; Zhang, Q.; Zhang, H.; Xiu, R. Effects of tumor necrosis factor- $\alpha$-induced exosomes on the endothelial cellular behavior, metabolism and bioenergetics. Microcirculation 2018, 26, e12515. [CrossRef] [PubMed]

44. Mathieu, M.; Martin-Jaular, L.; Lavieu, G.; Théry, C. Specificities of secretion and uptake of exosomes and other extracellular vesicles for cell-to-cell communication. Nat. Cell Biol. 2019, 21, 9-17. [CrossRef] [PubMed]

45. Javeed, N.; Mukhopadhyay, D. Exosomes and their role in the micro-/macro-environment: A comprehensive review. J. Biomed. Res. 2017, 31, 386-394. [CrossRef] [PubMed]

46. Ma, Y.; Mouton, A.J.; Lindsey, M.L. Cardiac macrophage biology in the steady-state heart, the aging heart, and following myocardial infarction. Transl. Res. 2018, 191, 15-28. [CrossRef]

47. Davidson, S.M.; Riquelme, J.A.; Zheng, Y.; Vicencio, J.M.; Lavandero, S.; Yellon, D.M. Endothelial cells release cardioprotective exosomes that may contribute to ischaemic preconditioning. Sci. Rep. 2018, 8, 1-9. [CrossRef]

48. Arnal, J.-F.; Dinh-Xuan, A.-T.; Pueyo, M.; Darblade, B.; Rami, J. Endothelium-derived nitric oxide and vascular physiology and pathology. Cell. Mol. Life Sci. 1999, 55, 1078-1087. [CrossRef]

49. Balligand, J.-L.; Kobzik, L.; Han, X.; Kaye, D.M.; Belhassen, L.; O’Hara, D.S.; Kelly, R.A.; Smith, T.W.; Michel, T. Nitric Oxidedependent Parasympathetic Signaling Is Due to Activation of Constitutive Endothelial (Type III) Nitric Oxide Synthase in Cardiac Myocytes. J. Biol. Chem. 1995, 270, 14582-14586. [CrossRef] 
50. García-Cardeña, G.; Martasek, P.; Masters, B.S.; Skidd, P.M.; Couet, J.; Li, S.C.; Lisanti, M.P.; Sessa, W.C. Dissecting the interaction between nitric oxide synthase (NOS) and caveolin. Functional significance of the nos caveolin binding domain in vivo. J. Biol. Chem. 1997, 272, 25437-25440. [CrossRef]

51. Sharma, A.; Sellers, S.; Stefanovic, N.; Leung, C.; Tan, S.M.; Huet, O.; Granville, D.J.; Cooper, M.E.; De Haan, J.B.; Bernatchez, P. Direct Endothelial Nitric Oxide Synthase Activation Provides Atheroprotection in Diabetes-Accelerated Atherosclerosis. Diabetes 2015, 64, 3937-3950. [CrossRef] [PubMed]

52. Ajmani, P.; Yadav, H.N.; Singh, M.; Sharma, P.L. Possible involvement of caveolin in attenuation of cardioprotective effect of ischemic preconditioning in diabetic rat heart. BMC Cardiovasc. Disord. 2011, 11, 43. [CrossRef] [PubMed]

53. Mastrocola, R.; Collino, M.; Penna, C.; Nigro, D.; Chiazza, F.; Fracasso, V.; Tullio, F.; Alloatti, G.; Pagliaro, P.; Aragno, M. Maladaptive Modulations of NLRP3 Inflammasome and Cardioprotective Pathways Are Involved in Diet-Induced Exacerbation of Myocardial Ischemia/Reperfusion Injury in Mice. Oxidative Med. Cell. Longev. 2015, 2016, 1-12. [CrossRef] [PubMed]

54. Mastrocola, R.; Aragno, M.; Alloatti, G.; Collino, M.; Penna, C.; Pagliaro, P. Metaflammation: Tissue-Specific Alterations of the NLRP3 Inflammasome Platform in Metabolic Syndrome. Curr. Med. Chem. 2018, 25, 1294-1310. [CrossRef] [PubMed]

55. Morishita, R.; Sugimoto, T.; Aoki, M.; Kida, I.; Tomita, N.; Moriguchi, A.; Maeda, K.; Sawa, Y.; Kaneda, Y.; Higaki, J.; et al. In vivo transfection of cis element 'decoy' against nuclear factor-kB binding site prevents myocardial infarction. Nat. Med. 1997, 3, 894-899. [CrossRef] [PubMed]

56. Minghua, W.; Zhijian, G.; Chahua, H.; Qiang, L.; Minxuan, X.; Luqiao, W.; Weifang, Z.; Peng, L.; Biming, Z.; Lingling, Y.; et al. Plasma exosomes induced by remote ischaemic preconditioning attenuate myocardial ischaemia/reperfusion injury by transferring miR-24. Cell Death Dis. 2018, 9, 1-14. [CrossRef]

57. Schopf, F.H.; Biebl, M.M.; Buchner, J. The HSP90 chaperone machinery. Nat. Rev. Mol. Cell Biol. 2017, 18, 345-360. [CrossRef] 